\title{
The Volcanic Evolution of Cerro Uturuncu: A High-K, Composite Volcano in the Back-Arc of the Central Andes of SW Bolivia
}

\author{
Gary S. Michelfelder ${ }^{1,2 *}$, Todd C. Feeley ${ }^{1}$, Alicia D. Wilder ${ }^{1}$ \\ ${ }^{1}$ Department of Earth Sciences, Montana State University, Bozeman, USA \\ ${ }^{2}$ Department of Geography, Geology and Planning, Missouri State University, Springfield, USA \\ Email: "gary.michelfelder@msu.montana.edu
}

Received 19 June 2014; revised 15 July 2014; accepted 12 August 2014

Copyright @ 2014 by authors and Scientific Research Publishing Inc.

This work is licensed under the Creative Commons Attribution International License (CC BY). http://creativecommons.org/licenses/by/4.0/

c) (i) Open Access

\begin{abstract}
Cerro Uturuncu, southwest Bolivia, is a high- $\mathrm{K}$, calc-alkaline, composite volcano constructed upon extremely thick continental crust approximately $125 \mathrm{~km}$ behind the arc-front of the Andean Central Volcanic Zone (CVZ). Eruptive activity occurred between 890 - $271 \mathrm{ka}$ in a single phase of volcanism lasting $\sim 620,000$ years. The edifice consists of a central cone and several flank vents where dacitic and andesitic lava flows and domes erupted. Volumes of individual eruptive units range from 0.1 to $\sim 10 \mathrm{~km}^{3}$; the composite volume of Uturuncu is $\sim 89 \mathrm{~km}^{3}$. In this paper, we present new field, petrographic, and geochemical data in an effort to understand the volcanic and magmatic evolution of Uturuncu. Lava flows and domes have a restricted range in whole rock compositions ranging from $61 \mathrm{wt} \%-67 \mathrm{wt} \% \mathrm{SiO}_{2}$; magmatic inclusions contained within these units have a larger range from $53 \mathrm{wt} \%$ - $64 \mathrm{wt} \% \mathrm{SiO}_{2}$. Typical phenocryst assemblages are plagioclase > orthopyroxene $>$ biotite $>>$ quartz and Fe-Ti oxides. $\mathrm{Pb}$ isotope ratios are characteristic of the southern CVZ by containing high ${ }^{207} \mathrm{~Pb} /{ }^{204} \mathrm{~Pb}$ and ${ }^{206} \mathrm{~Pb} /{ }^{204} \mathrm{~Pb}$ and moderate to high ${ }^{208} \mathrm{~Pb} /{ }^{204} \mathrm{~Pb}$. Sr and $\mathrm{Nd}$ isotope ratios indicate that Uturuncu magmas were modified by high ${ }^{87} \mathrm{Sr} /{ }^{86} \mathrm{Sr}$ and $l o w ~{ }^{143} \mathrm{Nd} /{ }^{144} \mathrm{Nd}$ felsic basement lithology during magma migration and differentiation. In all eruptive units, there is petrographic and geochemical evidence for magma mixing and mingling. In this regard, magma mixing and mingling is considered to be responsible for the small range in lava flow and dome compositions throughout the eruptive history of the center.
\end{abstract}

\section{Keywords}

Utrunucu, Volcanic Evolution, Central Volcanic Zone, Magmatic Inclusion

\footnotetext{
${ }^{*}$ Corresponding author.
}

How to cite this paper: Michelfelder, G.S., Feeley, T.C. and Wilder, A.D. (2014) The Volcanic Evolution of Cerro Uturuncu: A High-K, Composite Volcano in the Back-Arc of the Central Andes of SW Bolivia. International Journal of Geosciences, 5, 1263-1281. http://dx.doi.org/10.4236/ijg.2014.511105 


\section{Introduction}

Volcanism in the Central Volcanic Zone (CVZ) of the Andes is a prime example of active continental arc magmatism. Young (e.g., <6 Ma) volcanic rocks in the CVZ are dominantly andesitic to dacitic in composition with geochemical and petrographic features indicative of extensive crustal contamination during magma differentiation (e.g., [1]-[3]). Previous studies of CVZ volcanic rocks have greatly contributed to our understanding of the regional setting of the magmas [4] [5]; and references therein in addition to ignimbrite forming eruptions [6]-[9]; among others and volcanism along the modern arc-front [3] [10]. However, comprehensive studies of back-arc composite volcanoes are scarce, due in part, to their rarity and remote locations. As a result, studies of these systems are typically reconnaissance in nature and associated with regional studies [4] [5] [11]-[13].

The lack of comprehensive studies on individual back-arc composite volcanoes in the CVZ prompted a detailed field, petrologic and geochemical study of the back-arc center Cerro Uturuncu (6010 m; 22 15 'S, Figure 1). The objectives of this study are to discuss the volcanic evolution of an individual back-arc composite volcano and broadly assess petrogenetic processes affecting magma composition in the back-arc of the CVZ. This study of Uturuncu results from a reconnaissance petrologic and geophysical investigation by Sparks et al. [16]. These authors concluded Uturuncu exhibits stages of volcanism separated by periods of quiescence common at other intermediate composite centers in the CVZ. Currently, the system is in a period of dormancy as the most recent eruption occurred at $\sim 270 \mathrm{ka}$. Relatively long periods of quiescence are common at composite volcanoes as they been observed at other intermediate composition systems in the CVZ and elsewhere such as at Soufrière Hills Volcano, Montserrat [3] [17] [18]. In this paper, we build on the reconnaissance investigation of Sparks et al. [16] by furthering discussion of the volcanic history, field relationships, and petrography of volcanic rocks at Uturuncu. We also present a broad geochemical model to account for the restricted compositional diversity of magmas erupted at the volcano. More detailed discussion of the petrology and petrogenesis of Uturuncu magmas will ensue in a forth-coming paper.

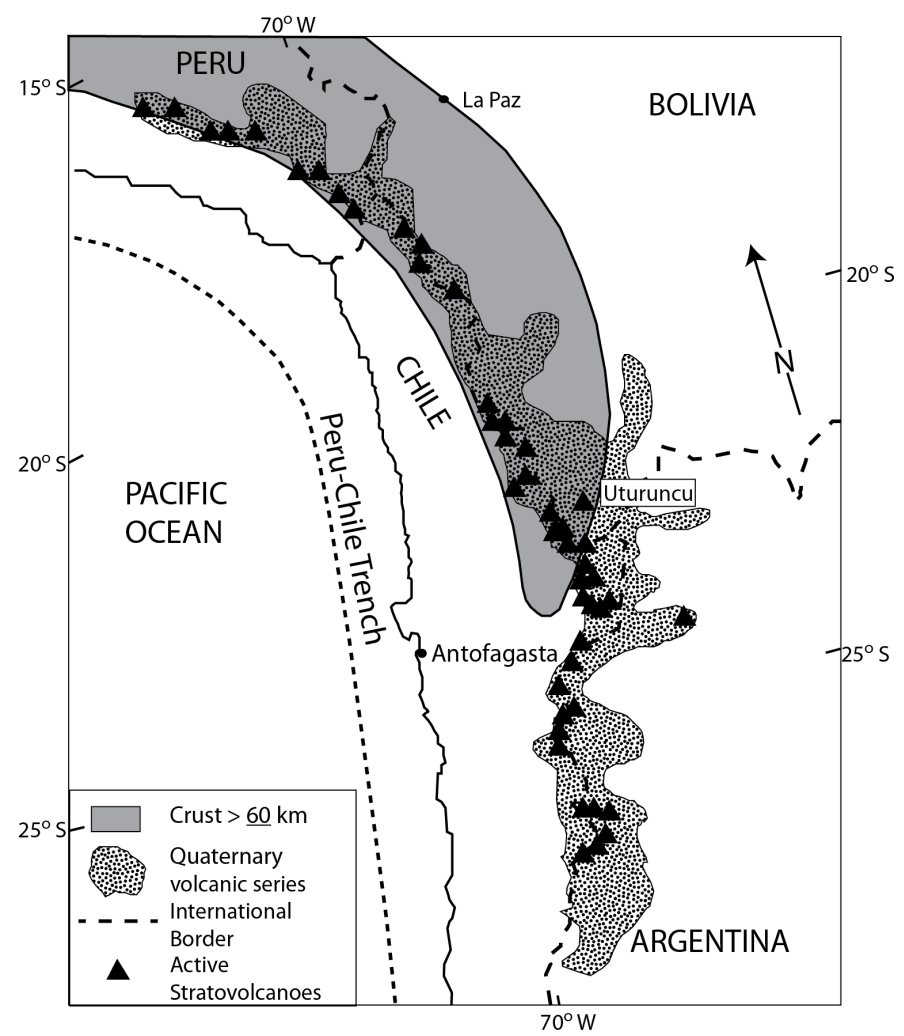

Figure 1. Map showing location of Andean Central Volcanic Zone (CVZ). Shaded area shows the region where crustal thickness exceeds $60 \mathrm{~km}$ [14] [15]; stippled region illustrates distribution of Quaternary volcanic rocks. Modified from Feeley and Hacker [2]. 


\section{Regional and Tectonic Setting}

The Andes are considered the classic example of a modern Cordilleran-type orogen formed by long-term subduction of oceanic lithosphere beneath continental lithosphere. The central Andes represents the type locality for this process owing to the great width of the orogen, immense crustal thickness (up to 70 - $80 \mathrm{~km}$ ) [19] and high elevations ( 4 - $6 \mathrm{~km}$ above sea level) [19] that occur over a vast area (Figure 1). The region composes one of the youngest and largest active silicic volcanic provinces with recent caldera formation. The CVZ contains $~ 20$ calderas that have erupted ignimbrites (large ash flow sheets) less than $10 \mathrm{Ma}$ and over 1100 late Cenozoic volcanic edifices [6] [7] [20].

The southern central Andes between $21^{\circ} \mathrm{S}-24^{\circ} \mathrm{S}$ is divided into three NW to SE trending geologic provinces based on structural similarities [19]. From east to west, these are the Eastern Cordillera (Cordillera Oriental), the Altiplano, and the Western Cordillera (Cordillera Occidental). The Eastern Cordillera comprises a classic thinskinned fold and thrust belt. The Altiplano is a broad plateau where undeformed late Miocene and younger ignimbrites overlie variably deformed mid-Miocene and older volcanic and sedimentary rocks. The Western Cordillera consists of a westward dipping monocline and the modern volcanic arc-front [19] [21]. Depths to the subducting slab at these latitudes range from $130 \mathrm{~km}$ at the arc-front to $250 \mathrm{~km}$ along the eastern boundary of the Altiplano [22] [23].

Late Cenozoic to modern volcanic rocks in the CVZ is divided into three groups based on similarities in composition and eruptive style [21] [24]. First, between $21^{\circ} \mathrm{S}-24^{\circ} \mathrm{S}$, large-volume, regionally extensive ignimbrites erupted from large caldera complexes on the Altiplano and Western Cordillera [6] [7] [25]. These rocks are calc-alkaline, homogeneous dacites to rhyolites. Second, basaltic andesitic to dacitic lava flows erupted from $23 \mathrm{Ma}$ to the present. At $21^{\circ} \mathrm{S}-22^{\circ} \mathrm{S}$, the largest volumes of these magmas erupted from composite volcanoes forming the peaks of the Western Cordillera. Baker and Francis [12] estimated the Western Cordillera contains $\sim 3000 \mathrm{~km}^{3}$ of these lavas between $21^{\circ} \mathrm{S}$ and $22^{\circ} \mathrm{S}$ latitude. Lavas associated with composite volcanoes extend for $\sim 200 \mathrm{~km}$ eastward onto the Altiplano, although volumes decrease sharply to $<800 \mathrm{~km}^{3}$. Uturuncu is associated with this group. Third, volumetrically minor alkali basalts erupted from small monogenetic centers to the east of the arc-front on the Altiplano north of $21^{\circ} \mathrm{S}$ [13] [26].

\section{Methods}

New whole rock samples of Uturuncu volcanic rocks were analyzed for major and trace element compositions at Washington State University, Pullman. Major and trace element compositions for 121 samples were acquired by X-ray fluorescence spectrometry (XRF) on a ThermoARL Advant'XP+ automated sequential wavelength spectrometer. Methods and errors for XRF analyses are described in Johnson et al. [27]. Additional trace element compositions, including the rare earth elements, for 45 samples, were acquired by inductively coupled plasma mass spectrometry (ICP-MS) on an Agilent 7700 ICP-MS. Methods and errors for trace element analyses are presented in detail in Jarvis [28]. Whole rock $\mathrm{Nd}$ and $\mathrm{Sr}$ isotopic ratios, for 30 samples, were acquired by thermal ionization mass spectrometry (TIMS) on a VG Sector 54, analyzed by five Faraday collectors in dynamic mode at New Mexico State University, Las Cruces. Pb isotopes were analyzed on a Thermo Finnigan Neptune multi-collector ICP-MS equipped with nine Faraday collectors and an ion counter at the University of California at Santa Barbara. Michelfelder et al. [29] describe in detail the methods for radiogenic isotopic analyses. Geologic mapping was performed using commercially purchased ASTER satellite imagery and field mapping.

\section{Geology and Eruptive History of Cerro Uturuncu}

In this section, we summarize the volcanic and petrographic features of the lava flows and domes at Cerro Uturuncu. Cerro Uturuncu is classified as a composite volcano [20] resulting from volcanism over 620,000 years [16]. Construction of the edifice of Cerro Uturuncu took place the back-arc of the CVZ approximately $125 \mathrm{~km}$ behind the modern arc front in the Altiplano region (Figure 1). The volcano is built upon a series of 5 Ma to 1 Ma ignimbrites erupted from large calderas complexes in the area [8] [9] [30] [31]. The eruptive history of Uturuncu is dominantly effusive with no evidence of explosive activity. Eruptive activity at Uturuncu predates the last glacial episode ( 11,000 ky [26]) in the area as evident by glacial valleys incising lava flows and the reformed southern and northern flanks mantled in places by moraines (Figure 2). Glacial incision has allowed for access to the potentially oldest lava flows erupted from Uturuncu. 


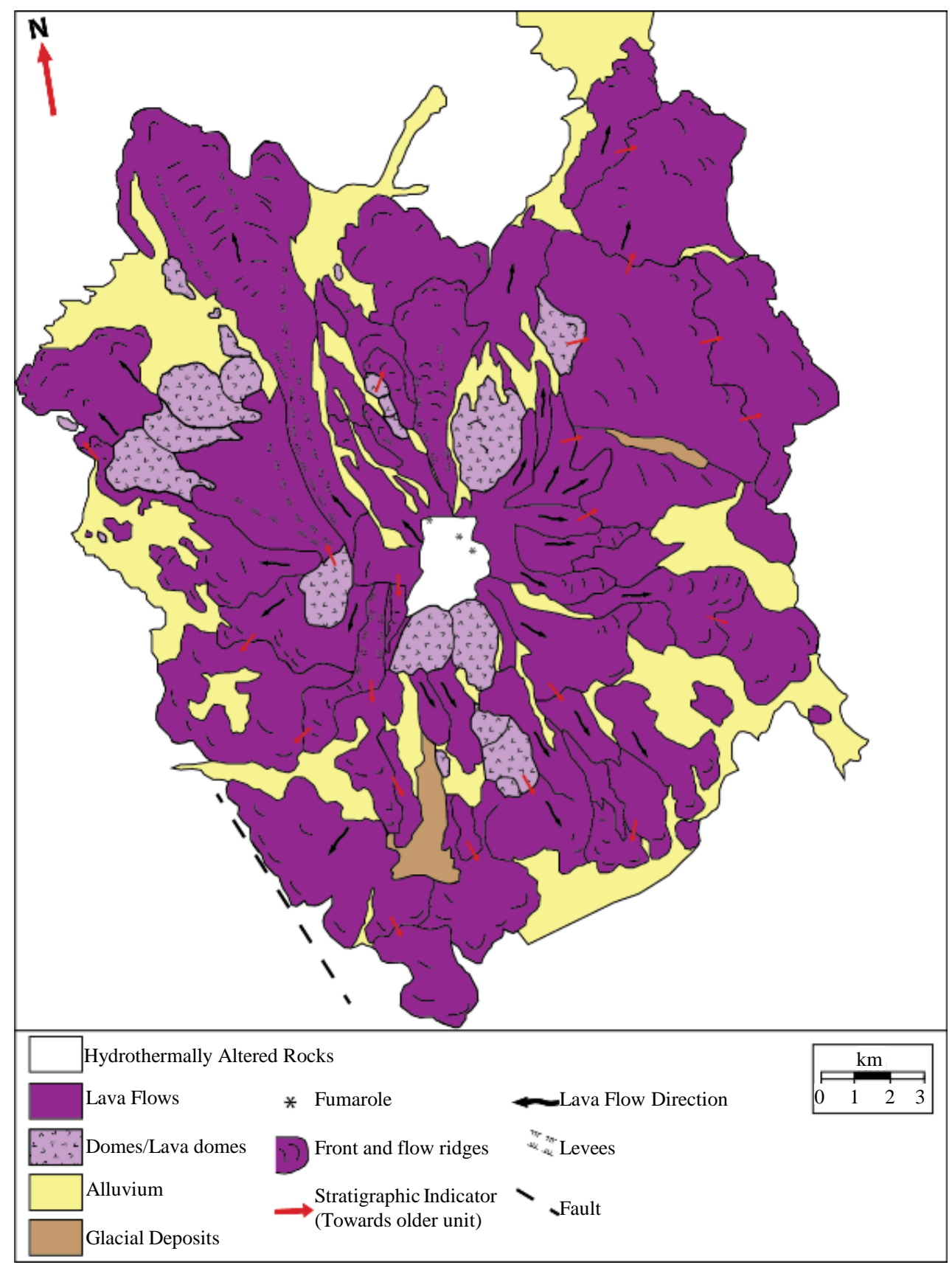

Figure 2. Simplified geologic map of Cerro Uturuncu based on field mapping and satellite imagery interpretation. Modified from Sparks et al. [16].

Active fumaroles producing hydrothermally altered volcanic rocks are present in the saddle between the two peaks of Uturuncu. Hydrothermal alteration, mining of altered rocks for sulfur and erosion of the stratigraphically youngest volcanic rocks has removed the interpreted location of the central vent. The presence of fumaroles suggests current activity beneath Cerro Uturuncu. Pritchard and Simmons [32] identified a $70 \mathrm{~km}$ diameter regional uplift centered on Uturuncu. This uplift, suggested to be the result of diapiric rise of new magma into a shallow chamber beneath the center [33], could lead to new activity at Uturuncu in the future.

Relatively few radiometric ages are available for Uturuncu lavas and domes. The available ages suggest two stages of volcanism between 890 - $271 \mathrm{ka} \mathrm{[16]} \mathrm{and} \mathrm{a} \mathrm{period} \mathrm{of} \mathrm{quiescence} \mathrm{from} 540$ - 470 ka. The stages described by Sparks et al. [16] are compositionally and petrographically similar, though erupted volumes of vol- 
canic rocks decrease with younger age.

\subsection{Morphology and Volume of Cerro Utrunucu}

Considered dormant, Cerro Uturuncu has not been the focus of intense study until recently. Fernandez et al. [34], Kussmaul et al. [11], Baker and Francis [12] and Hildreth and Moorebath [35] included Uturuncu in regional studies but did not investigate the volcanic history. Reconnaissance geologic mapping performed by Sparks et al. [16] identified $~ 50$ lava flows and domes with volumes ranging from $0.1-10 \mathrm{~km}^{3}$. Based on new mapping (Figure 2), as well as geochemical and stratigraphic criteria, the eruptive history of Uturuncu represents a single stage of activity spanning 620,000 years with an additional 45 lava flows and 10 domes identified as part of this study. Newly identified lava flows and domes observed during mapping and verified geochemically are stratigraphically between the $540 \mathrm{ka}$ and the $470 \mathrm{ka}$ lava flows. Volumes of these newly identified lava flows and domes are similar to those reported by Sparks et al. [16] with a total estimated volume of $\sim 89 \mathrm{~km}^{3}$. The suggested repose interval based on radiometric age dates and the number of erupted units is between 6000 and 8000 years.

The predominant rock types at Cerro Uturuncu are medium-grey, blocky to platy, orthopyroxene, biotite andesites and dacites. Dacites of relatively uniform compositions were the dominant magmas erupted, although significant volumes of andesite lava flows were erupted throughout the life span of the volcano. Flow fronts of lava flows range in thickness from $<5 \mathrm{~m}$ to over $200 \mathrm{~m}$ thick. Widths of flows vary with slope and are wider than thick for gentler slopes (Figure 2 \& Figure 3). Some lava flows extend for more than $10 \mathrm{~km}$ and traced back to the central vent (Figure 2), while smaller volume flows rarely extend more than 2 - $3 \mathrm{~km}$ from the vent. Many flows have internal flow folds and are autobrecciated at the terminus showing several meters of oxidation (Figure 3).

Domes occur throughout the volcano and suggest the activity was not restricted to a central vent, though lava flows cannot be trace to these flank vents. Piles of glassy, prismatically jointed blocks making up the exterior walls identified domes. Rare exposures of the interiors of domes are vesiculated ranging from $8 \%-23 \%$ of the total volume (Figure 3). Vesicles ranged in size from millimeter to centimeter scale.

\subsection{Petrography}

Mineralogically and petrographically, Uturuncu lava flows and domes are porphyritic to seriate. Domes are occasionally hiatal. Some lava flows have ophitic and poikilitic textures. Glomerocrysts containing orthopyroxene (OPX) and plagioclase common with occasional olivine observed in some lava flows. Modal compositions of Uturuncu volcanic rocks are variable in crystal content, but similar in mineral assemblage (Figure 4). Crystal contents range from 30\% - 53\% total volume for all lava flows and domes with domes containing the highest crystal volumes. Phenocryst phases include plagioclase $\left(\mathrm{An}_{42-94}\right)>\operatorname{OPX}\left(\mathrm{En}_{45-83}\right)>$ biotite $>>$ quartz, Fe-Ti oxides, and trace clinopyroxene (CPX), hornblende and olivine in micro-inclusions (Figure 4).

Plagioclase and OPX phenocrysts exhibit multiple textures. In the same eruptive unit, plagioclase phenocrysts textures include a combination of sieving, dissolution surfaces, growth zones, and clean crystals (Figure 5). Sieving occurs in both cores and rims of phenocrysts and dissolution surfaces commonly separate clear or sieved cores from zoned rims (Figure 5(B) \& Figure 5(C)). Large plagioclase phenocrysts ( $>0.5$ mm) are interpreted as xenocrysts because they contain cores riddled with abundant, irregular shaped glass inclusions and euhedral to subeuhedral rims with oscillatory chemical zoning from core to rim $\left(\mathrm{An}_{\text {core }}=46-92 ; \mathrm{An}_{\text {rims }}=44-88\right)$. Nearly all OPX crystals show some zoning. Chemically unzoned OPX are only associated with glomerocrysts and in groundmass crystals (Figure 5(A) \& Figure 5(D)). OPX crystals are Ca-poor at ( $\mathrm{Wo}_{06}$ or less) and represent two zoned populations [16]. The first contains Mg-poor cores $\left(E_{5 n}\right)$ and reverse zoned rims $\left(\operatorname{En}_{65-75}\right)$, and the second population contains Mg-rich cores $\left(\mathrm{En}_{65-80}\right)$ and normally zoned rims $\left(\mathrm{En}_{50-705}\right)$. Reaction rims of Fe-Ti oxides and OPX typically surrounds biotite phenocrysts over $0.5 \mathrm{~mm}$. Quartz and olivine phenocrysts, and microphenocrysts typically exhibit resorption textures suggesting they are most likely xenocrysts or antecrysts.

Groundmass of the lava flows and domes are hyalopilitic with mineral phases similar to phenocryst phases. Additional phases in the groundmass include glass, trace zircon, apatite, and occasional olivine. Groundmass plagioclase $\left(\mathrm{An}_{45-85}\right)$ crystals do not exhibit sieving seen in phenocrysts. Groundmass plagioclase and OPX $\left(\mathrm{En}_{46-75}\right)$ crystals occasionally show zoning and dissolution surfaces. Vesicles comprise approximately $8 \%$ - $23 \%$ of the mode in domes interiors and $0 \%-12 \%$ in lava flows. 


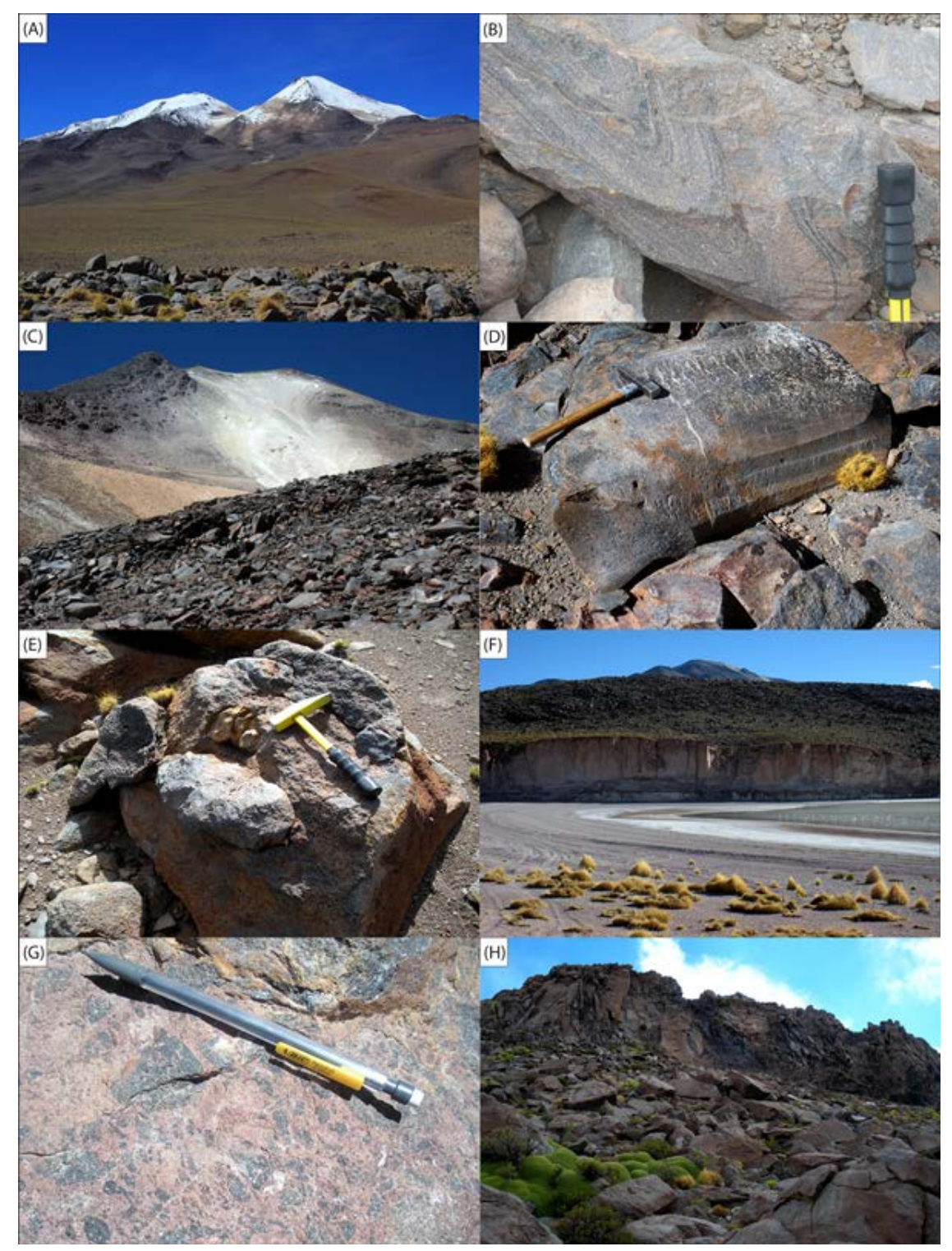

Figure 3. Representative views of Cerro Uturuncu geology. (A) View southeast towards the edifice of Uturuncu; (B) Typical flow folding in lava flows; (C) Hydrothermally altered remains of the edifice of Uturuncu produced by fumaroles; (D) Typical prismatically jointed block from exterior wall of a collapsed dome; (E) Andesite inclusions in an Uturuncu lava flow; (F) Typical flow front of an Uturuncu lava flow overlying APVC ignimbrite; (G) Oxidized autobrecciation found at the terminus of lava flows; (H) Pressure ridge found commonly found in lava flows over $20 \mathrm{~m}$ thick.

\subsection{Magmatic Inclusions}

A common occurrence in Uturuncu volcanic rocks is the presence of magmatic inclusions. Individual lava flows vary greatly in the volume of magmatic inclusions ranging from $\sim 0 \%-4 \%$. Three general populations of inclusions exist in Uturuncu lava flows and domes. Mineralogically and petrographically inclusions exhibit similar modes to the lavas and domes. With the exception of inclusions defining population 3, inclusions typically lack quartz and biotite and contain a higher volume of CPX and olivine compared to the host lava flows and domes.

The first population of inclusions is ellipsoidal with a porphyritic to hiatal texture and contains a thick, vesicle-free, glassy rim with vesiculated interiors. These inclusions are characterized by euhedral to subhedral parageneitcally early phenocrysts of OPX and plagioclase in varying proportions. Plagioclase phenocrysts range in 


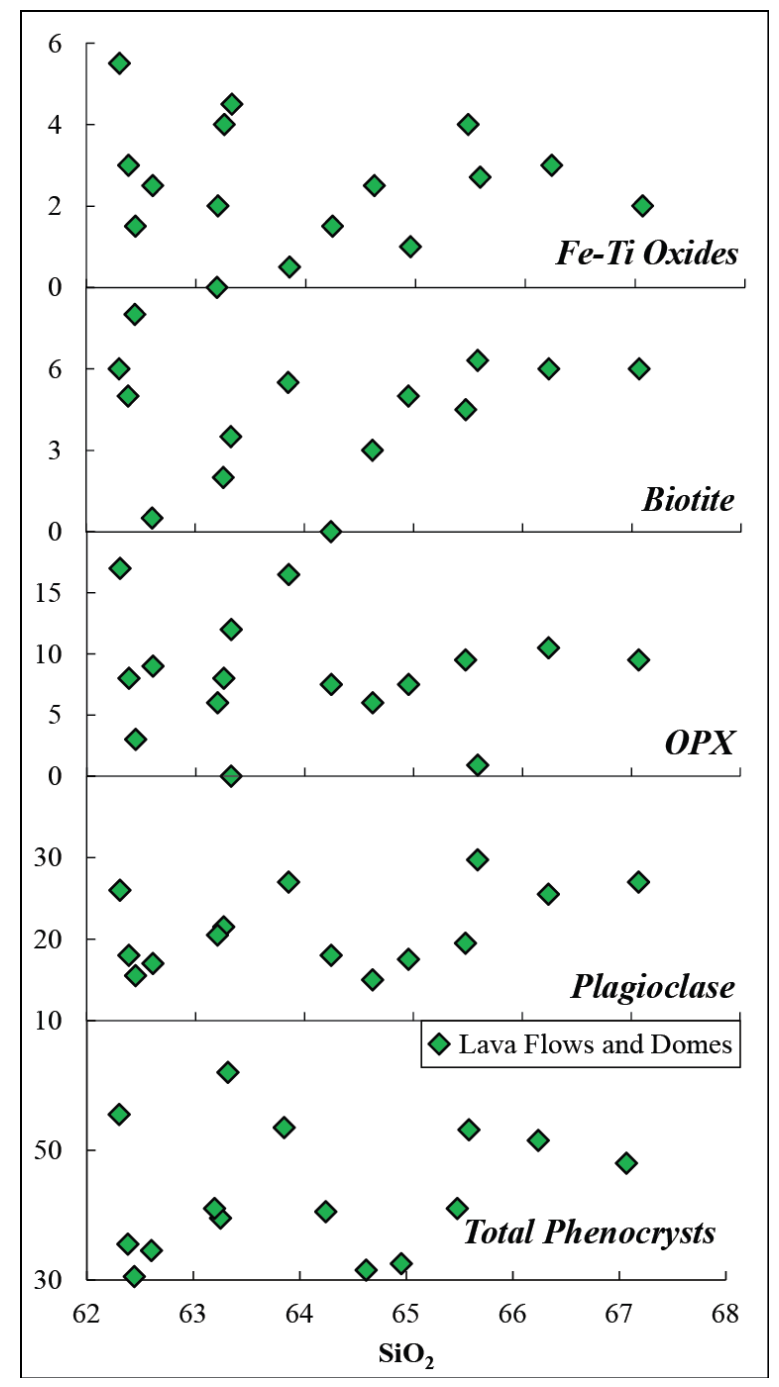

Figure 4. Modal percent phenocrysts versus $\mathrm{SiO}_{2}$ for representative Uturuncu lava and domes.

size from $0.25 \mathrm{~mm}$ to $1.5 \mathrm{~mm}$ along the long axis. Large plagioclase phenocrysts are interpreted as xenocrysts or antecrysts because they contain cores riddled with abundant, irregular shaped glass inclusions and euhedral rims and oscillatory zoning patterns similar to those observed in the host lava flows and domes. The groundmasses of these inclusions are hyalopilitic and are composed of microlite-sized $(<0.25 \mathrm{~mm})$ plagioclase crystals and Fe-Ti oxides in a glassy matrix. These inclusions are the most common type observed, and range in size from microinclusions ( $<3 \mathrm{~mm})$ to $\sim 5 \mathrm{~cm}$ in diameter although occasional larger inclusions were observed.

The second population of inclusions are non-vesiculated basaltic andesite clots, containing plagioclase $>$ OPX $>$ Fe-Ti oxides $>$ olivine $>$ amphibole \pm clinopyroxene. Hiatal to intergranular crystal sizes dominate this population of inclusions. The second population of inclusions lack glassy rims in contact with the host lava flow or dome as described above. The contacts of the inclusions are angular and defined by crystal boundaries. Crystal sizes range from microlite-size to crystals $\sim 1.5 \mathrm{~mm}$ along the long axis. Inclusion size varies from micro-inclusions $(\sim 3 \mathrm{~mm})$ to $\sim 10 \mathrm{~cm}$ in diameter. Hand specimen size samples of this inclusion population was only observed in two lava flows, although these inclusions may have been overlooked due to their similarity in color to the host lavas when weathered. Two additional lava flows and one dome contain micro-inclusions of this population.

Non-vesiculated micro-inclusions are distinct from the glomerocrysts observed lava flows and domes due to their crystal size and presence of rare amphibole. OPX phenocrysts are similar in size to the plagioclase though 


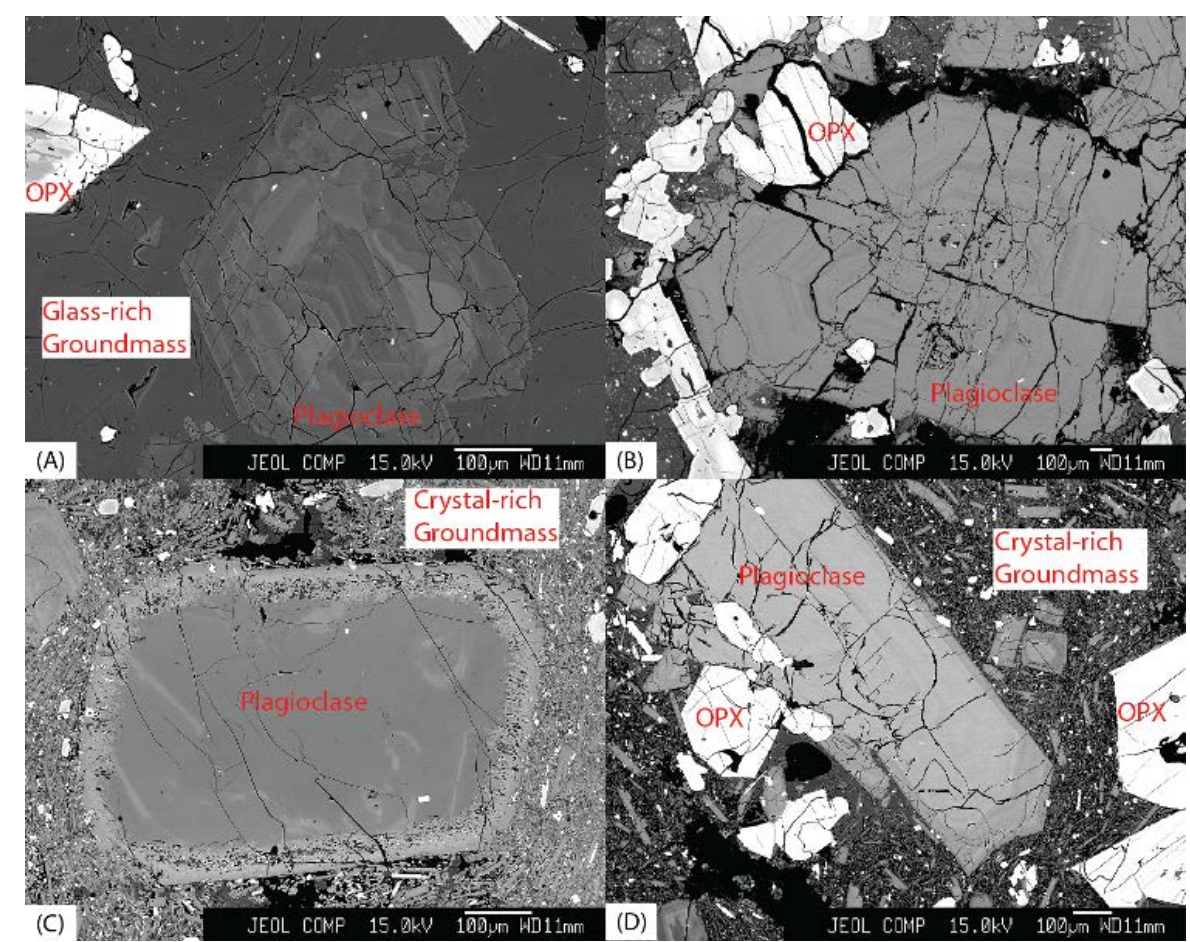

Figure 5. Back-scattered electron micrographs of Uturuncu volcanic rocks. (A) Plagioclase phenocryst exhibiting resoption surfaces and growth zones; (B) Glomerocryst composed of zoned OPX phenocrysts around a single sieved and zoned plagioclase phenocryst; (C) Dacite lava flow with a sieved, unzoned plagioclase phenocryst; and (D) a glomerocryst composed of unzoned OPX phenocrysts around zoned and unzoned plagioclase phenocrysts.

chemical zoning is not present. Some plagioclase phenocrysts show sieving and dissolution surfaces and all crystals over $0.5 \mathrm{~mm}$ contain growths zones. A reaction rim of OPX typically surrounds olivine phenocrysts. The groundmasses of the non-vesiculated inclusions are intergranular to hyalopilitic and are composed of microlite-sized acicular lath of plagioclase and blocky OPX.

Vesiculated and non-vesiculated magmatic inclusions (population 1 and 2) are common features observed in CVZ volcanic rocks as well as at other intermediate composition volcanic systems around the world [21] [36][38]. Magmatic inclusions, with or without vesiculation, represent blobs of mafic magma quenched in cooler, more silicic magma [36] due to the processes of magma mixing and mingling. This is our interpretation of inclusion populations 1 and 2 observed in Uturuncu lavas and domes.

The third population of inclusions observed does not exhibit the same mineralogy as the host lavas and domes. This population is dominantly hypidiomorphic to allotriomorphic granular with trace to rare glass $(0 \%-0.5 \%)$. Plagioclase and quartz dominate the mode of these inclusions with trace OPX and biotite. Plagioclase crystals are clear with no growth zones or dissolution surfaces observed. Quartz crystals show resorption along the corners of the crystals. Margins of these inclusions are angular and defined by the crystal boundaries. Textures observed in this population of inclusions suggest the same process does not produce these inclusions as populations 1 and 2. It is likely that inclusions in population 3 are xenoliths.

Sparks et al. [16] described two xenolith populations have a similar petrographic description to inclusions in population 3 of this study. These authors interpreted observed quartz-rich xenoliths to represent crustal partial melting of rocks trapped in a MASH zone [35]. It is our interpretation that xenoliths observed in this study represent basement rocks interacting with Uturuncu magmas during migration and differentiation. These xenoliths may represent the residue of a granodiorite crustal contaminant beneath Uturuncu.

A fourth inclusion population described by Sparks et al. [16] and was not observed in this study. These authors describe a noritic composition xenolith population found in multiple lava flows sampled in the study. These xenoliths contain mineral assemblages and similar mineral compositions to those observed in the lava flows and domes [16]. The adcumulate textures observed in these xenoliths suggested to these authors that these 
xenoliths represent adcumulates of early-formed crystals that segregated from hotter, less evolved residual magma related to the Uturuncu magmas [16].

\section{Whole Rock Geochemistry}

\subsection{Major and Trace Elements}

Figures 6-8 illustrate major- and trace-element compositions of lava flows, domes and inclusions. Table 1 and Table 2 present representative analyses of these data. These compositions define a high-K, calc-alkaline suite (Figure 6). $\mathrm{SiO}_{2}$ ranges from $61 \mathrm{wt} \%$ - $67 \mathrm{wt} \%$ for the lava flows and domes, $53 \mathrm{wt} \%$ - $64 \mathrm{wt} \%$ for the magmatic inclusions (population $1 \& 2$ ), and $78 \mathrm{wt} \%-79 \mathrm{wt} \%$ for the xenoliths (inclusion population 3). For the suite as a whole, contents of $\mathrm{CaO}, \mathrm{FeO}^{*}, \mathrm{MgO}, \mathrm{TiO}_{2}, \mathrm{MnO}, \mathrm{Yb}, \mathrm{Sr}$ and $\mathrm{Cr}$ decrease, and concentrations of $\mathrm{Na}_{2} \mathrm{O}$, $\mathrm{K}_{2} \mathrm{O}, \mathrm{P}_{2} \mathrm{O}_{5}, \mathrm{La}, \mathrm{Zr}, \mathrm{Ba}$ and $\mathrm{Rb}$ increase with increasing $\mathrm{SiO}_{2}$ concentrations (Figure 7 \& Figure 8). Compared to other centers in the CVZ [29], higher concentrations of are observed in LIL-element concentrations for Uturuncu volcanic rocks.

Consistent with petrography, xenolith samples do not exhibit the same geochemical trends observed in the lavas, domes, or inclusions (Figure 7 \& Figure 8) suggesting these xenoliths are trapped residue in a MASH zone or represent a crustal contaminant. Compared to other volcanic rock compositions at Uturuncu, compositions of the xenoliths are significantly lower for elements not compatible with quartz or plagioclase (Figure 7 \& Figure 8).

The compositional variation and trends observed versus $\mathrm{SiO}_{2}$ highlight the petrologic processes affecting the evolution of Uturuncu magmas. The linear trends observed in all major element compositions and the divergent linear trends in $\mathrm{MgO}, \mathrm{La}, \mathrm{Sr}, \mathrm{Y}$ and $\mathrm{Yb}$ suggest multiple components in magma evolution. These linear trends reflect magma mixing as a dominant process in the generation of the limited compositional diversity observed of lavas and domes at Uturuncu. Magmatic inclusion compositions are an extension of this trend at lower $\mathrm{SiO}_{2}$ contents.

\subsection{Radiogenic Isotopes}

Table 1 and Table 2 present, and Figure 9 illustrate radiogenic isotopic ratios for ${ }^{87} \mathrm{Sr} /{ }^{86} \mathrm{Sr},{ }^{143} \mathrm{Nd} /{ }^{144} \mathrm{Nd}$, and $\mathrm{Pb}$ isotopes of lavas and domes, inclusions and xenoliths. The range in ${ }^{87} \mathrm{Sr} /{ }^{86} \mathrm{Sr}$ and ${ }^{143} \mathrm{Nd} /{ }^{144} \mathrm{Nd}$ isotopic ratios for Uturuncu rocks is small compared to the range observed across the CVZ (Figure 9(B)) [4] [37]. In comparison with other individual CVZ composite cones, Uturuncu rocks have higher ${ }^{87} \mathrm{Sr} /{ }^{86} \mathrm{Sr}$ ratios and lower ${ }^{143} \mathrm{Nd} /{ }^{144} \mathrm{Nd}$ ratios and are more similar in comparison to ignimbrites erupted from Cerro Panizos on the eastern Altiplano or the $5 \mathrm{Ma}$ to 1 Ma Altiplano ignimbrites Uturuncu overlies (Figure 9(B)) [30] [39]. When compared to previously report isotopic analyses in reconnaissance or regional studies including volcanic rocks from Uturuncu, this study reports more isotopic variation [11] [12]. The ${ }^{87} \mathrm{Sr} /{ }^{86} \mathrm{Sr}$ isotopic compositions for the inclusions overlap the lowest ratios measured in the host lavas and domes (Figure 9(A) \& Figure 9(B)) suggesting extensive crustal contamination of the most mafic magmas observed in this study.

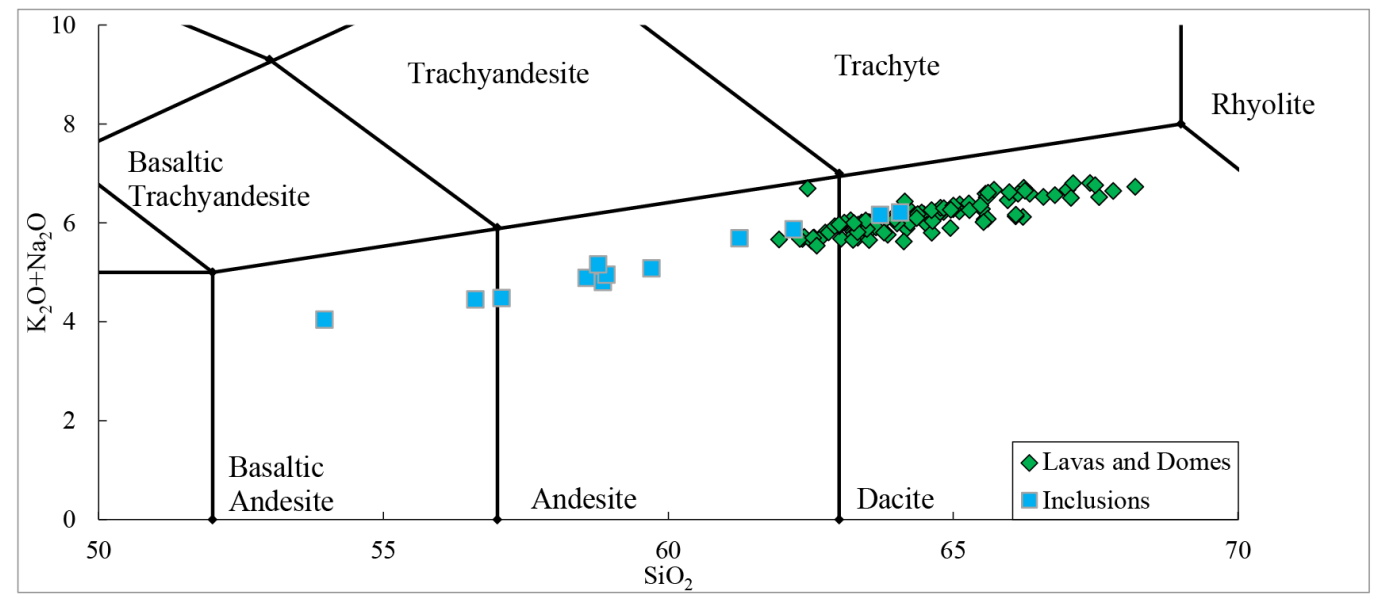

Figure 6. Total alkali concentrations versus $\mathrm{SiO}_{2}$ for Uturuncu lavas, domes and inclusions. 


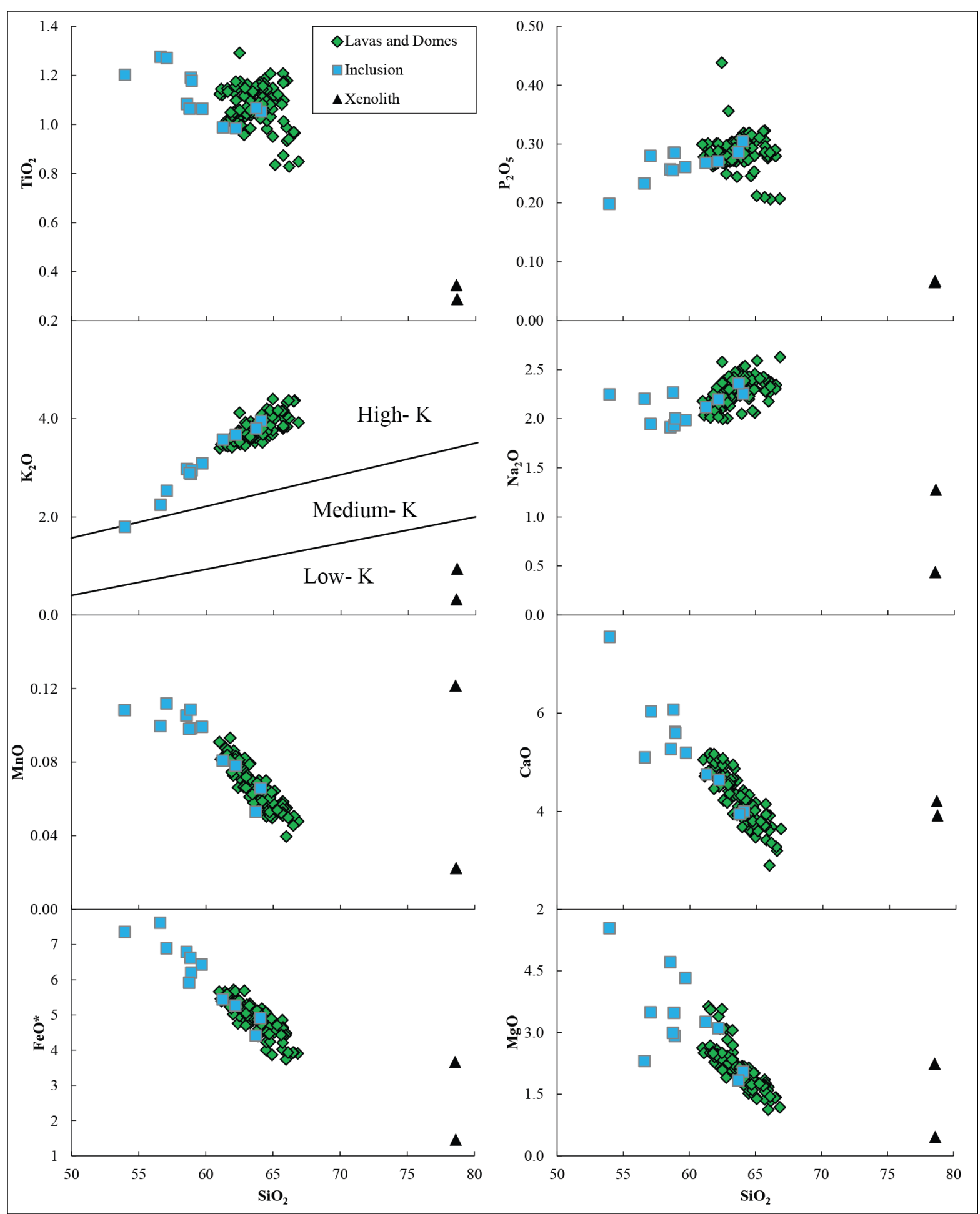

Figure 7. Major-element oxide concentrations versus $\mathrm{SiO}_{2}$ for Uturuncu lavas and domes, inclusions and xenoliths.

\section{Petrogenesis of Cerro Uturuncu Magmas}

In this section, we describe a simple working model to explain the limited compositional diversity observed in Uturuncu volcanic rocks. The intent of the proposed model is not a rigorous description of the petrogenesis of the magmas nor is the variables and compositions selected for assimilation-fractional crystallization and mag- 


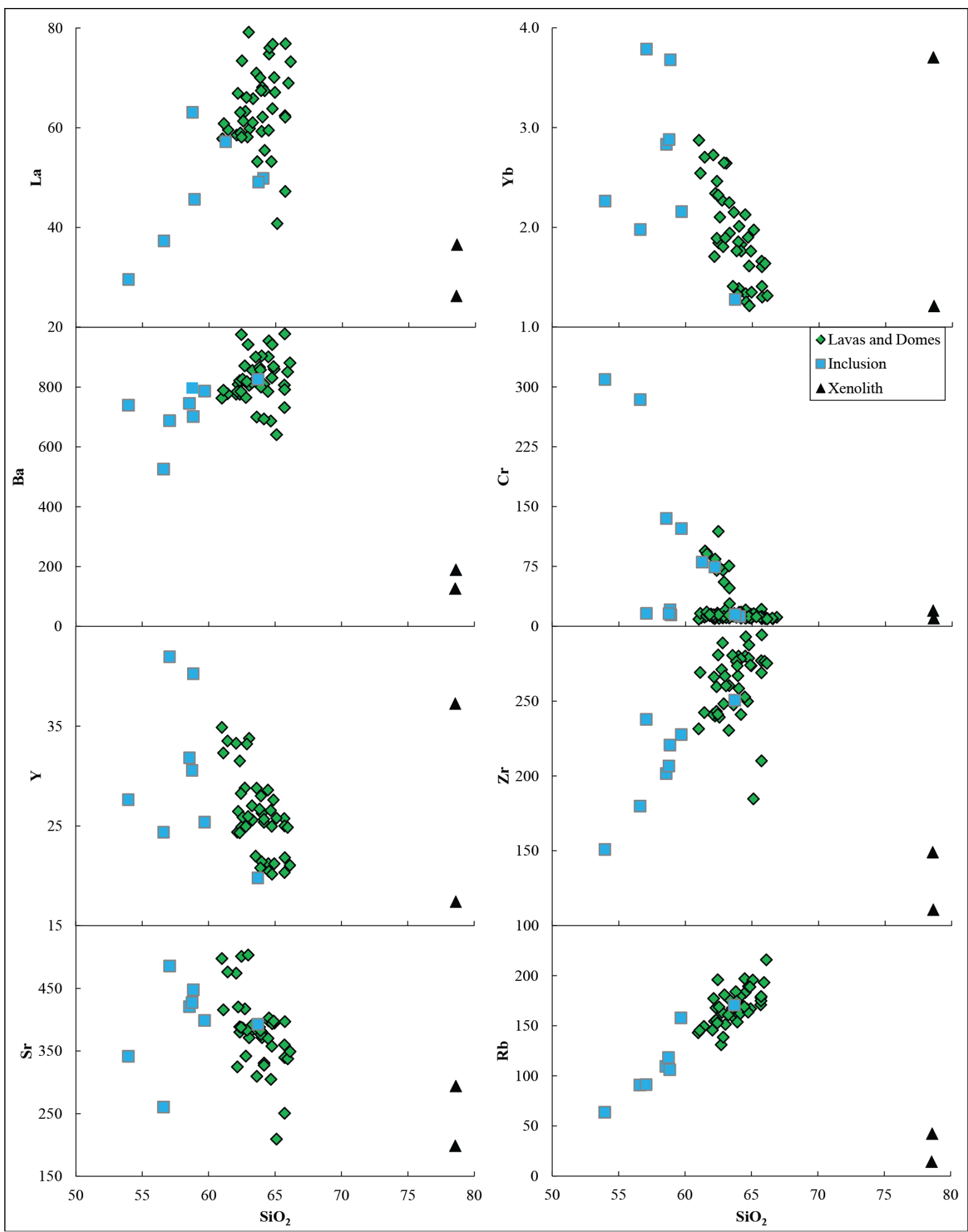

Figure 8. Trace-element concentrations versus $\mathrm{SiO}_{2}$ for Uturuncu lavas and domes, inclusions and xenoliths.

mamixing models intended to quantify the magmatic system beneath Uturuncu. The intent is to constrain the processes affecting compositional diversity of the rocks and serve as a point of reference in future studies of Uturuncu volcanic rocks. 
Table 1. Representative whole rock major-, trace-element concentrations and isotopic ratios analyses of Uturuncu lava flows and domes.

\begin{tabular}{|c|c|c|c|c|c|c|c|c|c|}
\hline & DM10A & DM28A & DM58A2 & DM73A2 & DM101A2 & GSM14 & GSM22 & GSM-49 & GSM-50 \\
\hline $\mathrm{SiO}_{2}$ & 65.55 & 63.33 & 62.30 & 63.04 & 65.61 & 66.10 & 65.00 & 64.15 & 64.84 \\
\hline $\mathrm{TiO}_{2}$ & 1.08 & 1.16 & 1.13 & 1.17 & 1.21 & 1.18 & 1.12 & 1.09 & 1.08 \\
\hline $\mathbf{A l}_{2} \mathbf{O}_{3}$ & 16.16 & 17.26 & 17.19 & 17.10 & 15.90 & 15.89 & 16.24 & 16.37 & 16.25 \\
\hline $\mathrm{FeO}^{*}$ & 4.81 & 5.29 & 5.73 & 5.57 & 4.85 & 4.65 & 5.10 & 4.79 & 4.93 \\
\hline MnO & 0.07 & 0.08 & 0.09 & 0.08 & 0.06 & 0.06 & 0.07 & 0.07 & 0.07 \\
\hline MgO & 1.87 & 2.27 & 2.60 & 2.46 & 1.85 & 1.73 & 1.86 & 2.30 & 2.11 \\
\hline $\mathrm{CaO}$ & 4.14 & 4.65 & 4.95 & 4.63 & 4.14 & 3.95 & 4.05 & 4.44 & 4.11 \\
\hline $\mathrm{Na}_{2} \mathrm{O}$ & 2.37 & 2.15 & 2.21 & 2.07 & 2.28 & 2.29 & 2.46 & 2.48 & 2.29 \\
\hline $\mathbf{K}_{2} \mathbf{O}$ & 3.70 & 3.54 & 3.49 & 3.61 & 3.79 & 3.87 & 3.81 & 3.95 & 4.01 \\
\hline $\mathbf{P}_{2} \mathbf{O}_{5}$ & 0.25 & 0.27 & 0.30 & 0.28 & 0.31 & 0.29 & 0.28 & 0.36 & 0.32 \\
\hline LOI (\%) & 0.99 & 0.65 & 0.43 & 1.47 & 0.00 & 0.30 & 0.93 & 1.24 & 0.95 \\
\hline Total & 100.00 & 100.00 & 100.00 & 100.00 & 100.00 & 100.00 & 100.00 & 100.00 & 100.00 \\
\hline La & 53.18 & 63.26 & 58.50 & 66.88 & 62.42 & 62.12 & 67.41 & 79.14 & 70.02 \\
\hline $\mathrm{Ce}$ & 108.68 & 126.92 & 118.34 & 138.06 & 129.40 & 128.55 & 137.37 & 154.36 & 141.18 \\
\hline Pr & 13.05 & 15.17 & 13.96 & 16.62 & 15.65 & 15.23 & 16.73 & 17.80 & 16.69 \\
\hline Nd & 49.52 & 56.99 & 52.67 & 62.32 & 59.33 & 57.58 & 62.93 & 65.53 & 62.11 \\
\hline Sm & 9.64 & 10.84 & 10.19 & 11.50 & 11.41 & 11.08 & 11.43 & 11.71 & 11.42 \\
\hline Eu & 1.80 & 2.10 & 1.98 & 1.88 & 2.04 & 2.01 & 1.88 & 2.13 & 1.97 \\
\hline Gd & 7.68 & 8.36 & 8.23 & 7.95 & 8.48 & 8.25 & 8.16 & 8.44 & 8.36 \\
\hline $\mathbf{T b}$ & 1.11 & 1.22 & 1.25 & 1.11 & 1.17 & 1.15 & 1.11 & 1.14 & 1.18 \\
\hline Dy & 5.89 & 6.50 & 6.96 & 5.59 & 5.96 & 5.83 & 5.62 & 5.76 & 6.07 \\
\hline Ho & 1.03 & 1.15 & 1.31 & 0.94 & 0.99 & 0.96 & 0.97 & 1.00 & 1.04 \\
\hline Er & 2.44 & 2.84 & 3.29 & 2.24 & 2.28 & 2.18 & 2.29 & 2.42 & 2.40 \\
\hline $\mathbf{T m}$ & 0.33 & 0.38 & 0.45 & 0.30 & 0.29 & 0.29 & 0.30 & 0.32 & 0.31 \\
\hline $\mathbf{Y b}$ & 1.90 & 2.27 & 2.72 & 1.71 & 1.66 & 1.60 & 1.76 & 1.89 & 1.76 \\
\hline Lu & 0.27 & 0.33 & 0.40 & 0.24 & 0.23 & 0.22 & 0.25 & 0.28 & 0.25 \\
\hline Ba & 686 & 870 & 776 & 784 & 807 & 791 & 809 & 942 & 866 \\
\hline Th & 19.4 & 21.4 & 18.7 & 24.7 & 21.9 & 21.8 & 24.5 & 25.2 & 24.9 \\
\hline Nb & 18.2 & 20.7 & 20.8 & 18.4 & 22.1 & 21.7 & 18.3 & 26.5 & 22.1 \\
\hline $\mathbf{Y}$ & 27 & 29 & 33 & 24 & 26 & 25 & 26 & 26 & 27 \\
\hline Hf & 6.6 & 7.2 & 6.4 & 7.4 & 7.3 & 7.1 & 7.3 & 7.1 & 7.3 \\
\hline Ta & 1.4 & 1.5 & 1.5 & 1.3 & 1.6 & 1.5 & 1.3 & 1.6 & 1.5 \\
\hline $\mathbf{U}$ & 4.4 & 3.7 & 3.7 & 4.5 & 3.9 & 4.0 & 4.4 & 4.7 & 4.5 \\
\hline $\mathbf{P b}$ & 20.9 & 21.7 & 20.4 & 23.4 & 21.7 & 21.8 & 22.5 & 21.6 & 22.7 \\
\hline $\mathbf{R b}$ & 167 & 131 & 146 & 177 & 171 & 175 & 179 & 181 & 184 \\
\hline Cs & 7.9 & 4.3 & 5.2 & 6.3 & 5.2 & 4.9 & 5.4 & 6.5 & 6.4 \\
\hline Sr & 305 & 417 & 474 & 325 & 360 & 340 & 327 & 503 & 388 \\
\hline $\mathrm{Zr}$ & 249.8 & 271.0 & 241.1 & 266.0 & 277.0 & 268.9 & 278.2 & 266.7 & 276.4 \\
\hline${ }^{87} \mathrm{Sr} /{ }^{86} \mathrm{Sr}$ & 0.714570 & 0.712956 & 0.711294 & 0.712738 & 0.714300 & 0.714519 & 0.713692 & 0.711002 & 0.712468 \\
\hline${ }^{144} \mathrm{Nd} /{ }^{143} \mathrm{Nd}$ & 0.512148 & 0.512246 & 0.512179 & 0.512159 & 0.512172 & 0.512163 & 0.512202 & 0.512247 & 0.512163 \\
\hline
\end{tabular}


Table 2. Representative whole rock major-, trace-element concentrations and isotopic ratios analyses of Uturuncu magmatic inclusions and xenoliths.

\begin{tabular}{|c|c|c|c|c|c|c|c|c|c|}
\hline & UTU 13N & UTU 17N & UTU 28N1 & $\begin{array}{l}\text { UTU } \\
28 N 3\end{array}$ & UTU 56N & $\begin{array}{l}\text { UTU } \\
58 N 1\end{array}$ & $\begin{array}{l}\text { UTU } \\
69 N 3\end{array}$ & $\begin{array}{l}\text { UTU } \\
28 X\end{array}$ & $\begin{array}{l}\text { UTU } \\
56 N 3\end{array}$ \\
\hline & Inclusion & Inclusion & Inclusion & Inclusion & Inclusion & Inclusion & Inclusion & Xenolith & Xenolith \\
\hline $\mathrm{SiO}_{2}$ & 54.0 & 56.6 & 59.7 & 58.6 & 58.9 & 57.1 & 63.7 & 78.6 & 78.6 \\
\hline $\mathrm{TiO}_{2}$ & 1.20 & 1.28 & 1.06 & 1.08 & 1.19 & 1.27 & 1.07 & 0.29 & 0.34 \\
\hline $\mathbf{A l}_{2} \mathbf{O}_{3}$ & 15.59 & 16.81 & 16.41 & 16.26 & 17.24 & 18.28 & 15.81 & 10.00 & 8.62 \\
\hline $\mathrm{FeO}^{*}$ & 7.35 & 7.62 & 6.43 & 6.78 & 6.62 & 6.89 & 4.41 & 1.46 & 3.66 \\
\hline MnO & 0.11 & 0.10 & 0.10 & 0.11 & 0.11 & 0.11 & 0.05 & 0.02 & 0.12 \\
\hline MgO & 5.54 & 2.31 & 4.33 & 4.71 & 3.48 & 3.49 & 1.83 & 0.46 & 2.24 \\
\hline $\mathrm{CaO}$ & 7.55 & 5.10 & 5.19 & 5.27 & 5.61 & 6.03 & 3.94 & 3.91 & 4.21 \\
\hline $\mathrm{Na}_{2} \mathrm{O}$ & 2.25 & 2.20 & 1.99 & 1.91 & 1.93 & 1.95 & 2.36 & 1.28 & 0.44 \\
\hline $\mathbf{K}_{2} \mathbf{O}$ & 1.79 & 2.24 & 3.09 & 2.97 & 2.87 & 2.53 & 3.80 & 0.94 & 0.32 \\
\hline $\mathbf{P}_{2} \mathbf{O}_{5}$ & 0.20 & 0.23 & 0.26 & 0.26 & 0.29 & 0.28 & 0.29 & 0.07 & 0.07 \\
\hline Total & 95.55 & 94.50 & 98.56 & 97.92 & 98.19 & 97.91 & 97.28 & 97.03 & 98.58 \\
\hline La & 29.55 & 37.30 & 57.16 & 49.82 & 45.62 & 49.09 & 63.06 & 36.54 & 26.25 \\
\hline Ce & 51.98 & 64.02 & 113.16 & 98.03 & 91.52 & 98.21 & 130.97 & 79.27 & 56.05 \\
\hline Pr & 7.50 & 8.62 & 13.47 & 11.92 & 11.13 & 12.11 & 15.01 & 10.10 & 7.31 \\
\hline Nd & 29.71 & 32.90 & 50.06 & 45.50 & 43.26 & 46.75 & 55.64 & 38.70 & 27.64 \\
\hline Sm & 6.62 & 6.80 & 9.60 & 8.92 & 8.77 & 9.65 & 10.38 & 8.06 & 6.77 \\
\hline Eu & 1.52 & 1.86 & 1.78 & 1.87 & 1.92 & 2.07 & 1.85 & 1.38 & 0.91 \\
\hline Gd & 6.21 & 6.00 & 7.25 & 7.61 & 8.01 & 8.59 & 7.32 & 5.85 & 6.10 \\
\hline $\mathbf{T b}$ & 0.97 & 0.91 & 1.03 & 1.12 & 1.30 & 1.39 & 0.98 & 0.84 & 1.13 \\
\hline Dy & 5.55 & 5.02 & 5.41 & 6.30 & 7.85 & 8.30 & 4.80 & 4.21 & 6.98 \\
\hline Ho & 1.08 & 0.93 & 1.00 & 1.22 & 1.58 & 1.67 & 0.79 & 0.71 & 1.43 \\
\hline Er & 2.69 & 2.26 & 2.50 & 3.20 & 4.18 & 4.41 & 1.72 & 1.63 & 3.90 \\
\hline Tm & 0.37 & 0.33 & 0.36 & 0.46 & 0.60 & 0.62 & 0.23 & 0.21 & 0.59 \\
\hline $\mathbf{Y b}$ & 2.26 & 1.98 & 2.16 & 2.83 & 3.68 & 3.79 & 1.28 & 1.21 & 3.70 \\
\hline Lu & 0.34 & 0.31 & 0.33 & 0.44 & 0.56 & 0.59 & 0.18 & 0.17 & 0.55 \\
\hline $\mathbf{B a}$ & 739 & 525 & 786 & 745 & 701 & 687 & 825 & 189 & 126 \\
\hline Th & 7 & 9 & 21 & 14 & 13 & 15 & 23 & 14 & 13 \\
\hline Nb & 14 & 16 & 18 & 17 & 18 & 19 & 19 & 10 & 10 \\
\hline $\mathbf{Y}$ & 28 & 24 & 25 & 32 & 40 & 42 & 20 & 17 & 37 \\
\hline Hf & 4.06 & 4.89 & 6.24 & 5.48 & 5.99 & 6.38 & 6.96 & 3.13 & 4.30 \\
\hline Ta & 1.07 & 1.22 & 1.29 & 1.11 & 1.19 & 1.29 & 1.29 & 1.12 & 1.12 \\
\hline $\mathbf{U}$ & 3.07 & 3.42 & 4.06 & 2.59 & 2.26 & 2.30 & 4.44 & 3.48 & 5.63 \\
\hline $\mathbf{P b}$ & 10 & 10 & 18 & 15 & 15 & 16 & 22 & 12 & 4 \\
\hline $\mathbf{R b}$ & 64 & 91 & 158 & 109 & 106 & 91 & 170 & 42 & 14 \\
\hline Cs & 4.49 & 6.12 & 6.08 & 2.68 & 2.44 & 2.80 & 5.89 & 1.91 & 0.55 \\
\hline $\mathrm{Sr}$ & 341 & 260 & 399 & 421 & 448 & 485 & 393 & 294 & 199 \\
\hline $\mathrm{Zr}$ & 151 & 180 & 228 & 202 & 221 & 238 & 251 & 111 & 149 \\
\hline${ }^{87} \mathrm{Sr} /{ }^{86} \mathrm{Sr}$ & & & 0.710339 & 0.710456 & & & & 0.713682 & 0.714553 \\
\hline
\end{tabular}




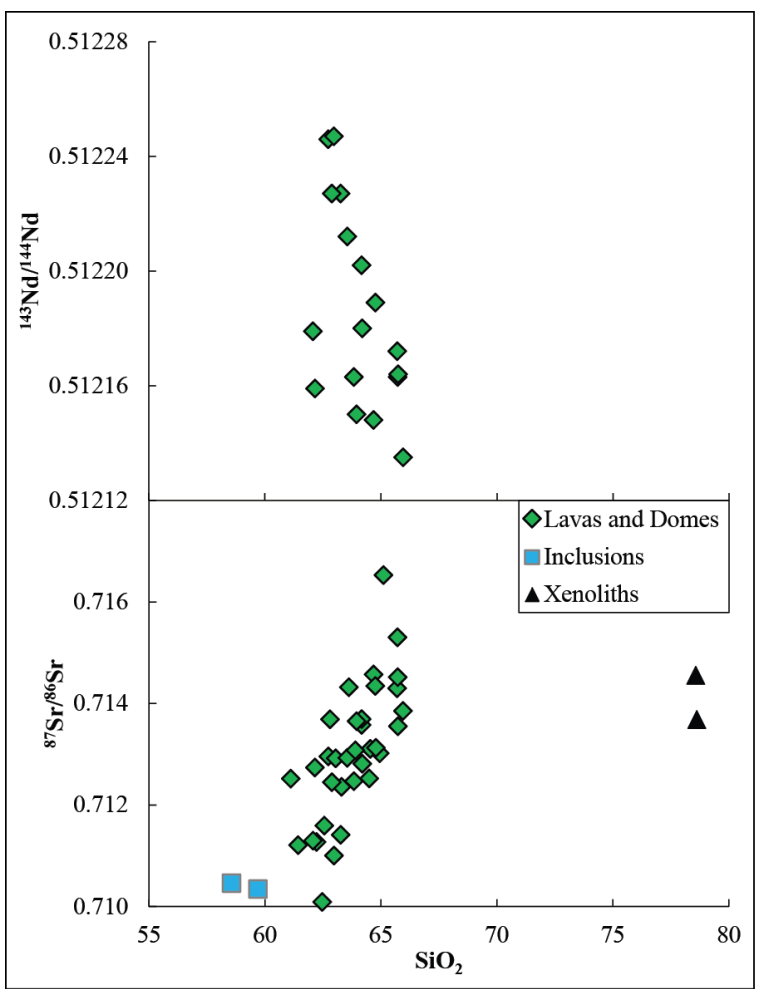

(A)

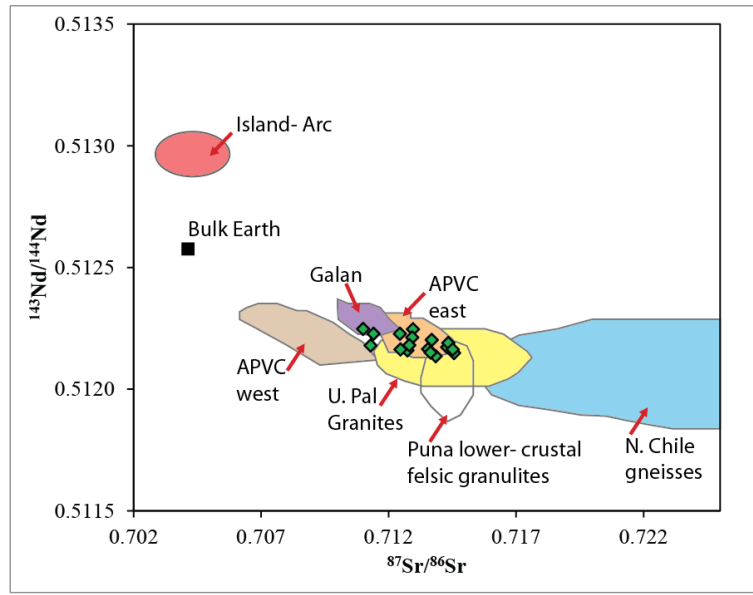

(B)

Figure 9. (A) Nd isotope and $\mathrm{Sr}$ isotope ratios for Uturuncu lavas and domes; (B) ${ }^{143} \mathrm{Nd} /{ }^{144} \mathrm{Nd}$ ratios versus ${ }^{87} \mathrm{Sr} /{ }^{86} \mathrm{Sr}$ ratios for Uturuncu volcanic rocks.

The lavas and domes have a large range of ${ }^{87} \mathrm{Sr} /{ }^{86} \mathrm{Sr}$ ratios for a narrow range of ${ }^{143} \mathrm{Nd} /{ }^{144} \mathrm{Nd}$ ratios (Figure 9(B)). Assimilation of crustal rocks with high ${ }^{87} \mathrm{Sr} /{ }^{86} \mathrm{Sr}$ ratios but similar ${ }^{143} \mathrm{Nd} /{ }^{144} \mathrm{Nd}$ ratios explains the observed trend. Figure 10 illustrates six scenarios using different composition contaminants and different partition coefficients dependent on the crustal composition. The lower crustal contaminant is a garnet-sillimanite-gneiss xenolith described by McLeod et al. [40] from the southern CVZ. We selected this composition because of petrographic similarities to a sillimanite-gneiss xenolith described by Sparks et al. [16] from Uturuncu lavas. The upper crustal contaminant used in the models is Paleozoic granite from Sierra de Moreno described by Lucassen et al. [41]. These granites are petrographically similar to the xenolith observed in this study. We contaminate two primitive basalt compositions with lower and upper crustal contaminants: one from Davidson and de Silva [13] for basalts from the central Altiplano, and a second from Hernando et al. [42] for pre-caldera basalts from the Payún Matrú volcanic field in western Argentina's Southern Volcanic Zone. Table 3 presents concentrations and isotopic ratios of the contaminants and basalts.

Model curves labeled AFC ( $D=1.7)$ and AFC $(D=1.5)$ were constructed to simulate the effects of differentiation on two potential parental magmas compositions contaminated by a highly evolved crustal contaminant (Figure 10). Bulk distribution coefficients of 1.5 and 1.7 are high for andesites, but the decrease of $\mathrm{Sr}$ content with increasing $\mathrm{SiO}_{2}$ content and in increase of $\mathrm{Rb} / \mathrm{Sr}$ ratios with increasing ${ }^{87} \mathrm{Sr} /{ }^{86} \mathrm{Sr}$ ratios suggest $\mathrm{Sr}$ was compatible during differentiation. The curve AFC $(\mathrm{D}=0.1)$ was constructed to simulate the effects of differentiation in the lower crust compared to curves for the upper crust. A bulk distribution coefficient of 0.1 is considered appropriate for this composition based on regional studies that have shown an increase in $\mathrm{Sr} / \mathrm{Y}$ ratio with a decrease in ${ }^{87} \mathrm{Sr} /{ }^{86} \mathrm{Sr}$ ratios reflects incompatibility of $\mathrm{Sr}$ in garnet-stable/plagioclase-unstable-hybridized crust [29] [44] [45].

${ }^{87} \mathrm{Sr} /{ }^{86} \mathrm{Sr}$ and ${ }^{143} \mathrm{Nd} /{ }^{144} \mathrm{Nd}$ ratios for Uturuncu lavas and domes create an array consistent with assimilation of old radiogenic basement rocks with relatively non-radiogenic $\mathrm{Nd}$ and radiogenic $\mathrm{Sr}$. High $\mathrm{Rb} / \mathrm{Sr}$ ratios suggest these basement rocks were also felsic in composition as opposed to noritic as could be interpreted from the presence of noritic composition xenoliths described by Sparks et al. [16]. High silica, quartz-feldspathic xeno- 


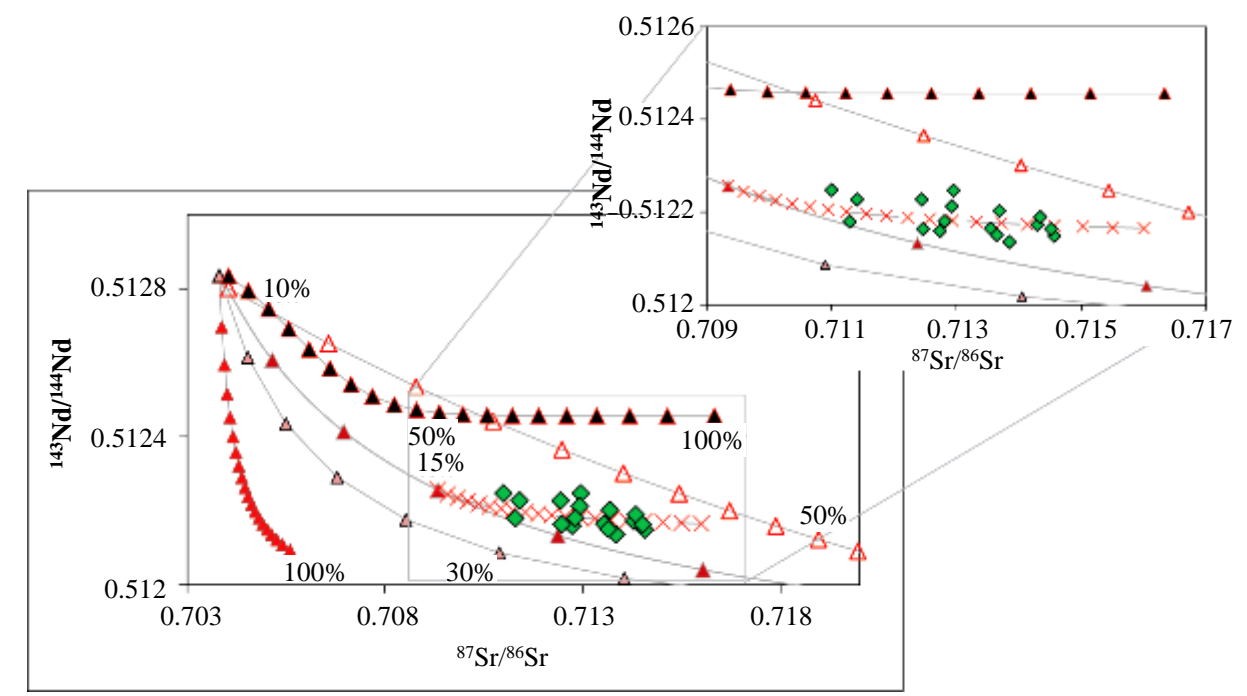

(A)

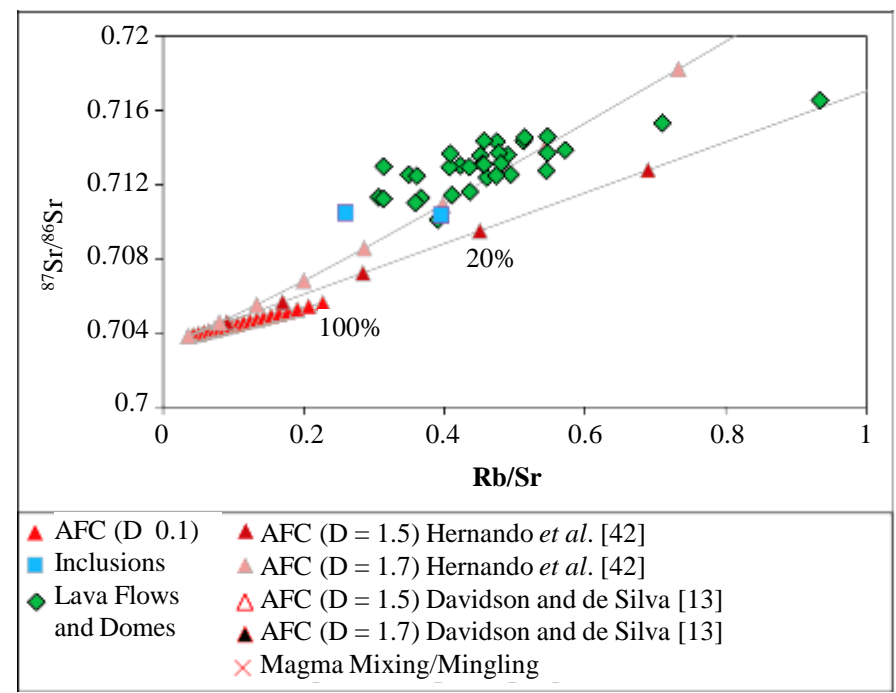

(B)

Figure 10. (A) Nd Isotope and Sr isotope constraints on bulk mixing and assimilation fractional crystallization (AFC) [43] models for Uturuncu lava flows and domes. (B) ${ }^{87} \mathrm{Sr} /{ }^{86} \mathrm{Sr}$ ratios versus $\mathrm{Rb} / \mathrm{Sr}$ ratios for Uturuncu lava flows, domes and inclusions with AFC models of primary melts discussed in text and in Table 3 .

Table 3. Trace element concentrations and isotopic ratios of basement rocks and primary basalts used in geochemical modeling.

\begin{tabular}{ccccccccc}
\hline & Sample Type & Location & $\mathrm{Rb}$ & $\mathrm{Sr}$ & $\mathrm{Nd}$ & ${ }^{87} \mathrm{Sr} /{ }^{86} \mathrm{Sr}$ & ${ }^{143} \mathrm{Nd} /{ }^{144} \mathrm{Nd}$ & Reference \\
\hline Py-5 & Basalt & $\begin{array}{c}\text { PayúnMatrú } \\
\text { volcanic field }\end{array}$ & 27 & 751 & 24.4 & 0.703813 & 0.512834 & Hernando et al. [42] \\
4/23 & Granite & Sierra de Moreno & 173 & 40 & 11.65 & 0.76261 & 0.512456 & Lucassen et al. [41] \\
BC93PAX12 & Grt-sill gneiss & Bolivia & 27.3 & 18.5 & 22.8 & 0.717314 & 0.511966 & McLeod et al. [40] \\
BC9016a & Basalt & Central Altiplano & 23 & 936 & 40.1 & 0.704052 & 0.512801 & Davidson and de Silva [13] \\
\hline
\end{tabular}

liths, observed in this study, and similar to xenoliths interpreted by Sparks et al. [16] to be remnants of a crustal hot zone could represent this contaminant. 


\section{Volcanic Hazards}

Cerro Uturuncu has historically been inactive and glacial erosion suggests that the volcano is in a period of dormancy. However, new geophysical data has shown a concentric uplift centered on Uturuncu for the past 20 years with the potential to initiate future eruptions [32] [33]. According to the spatial distribution of previously erupted lava flows, it is difficult to predict the likeliness of where a lava flow will occur during a future potential eruption. In addition, the injection of new magma beneath the central vent could cause instability of the highly altered hydrothermal rocks composing the summit potentially leading to partial collapse of the vent and debris avalanches towards the north. This event has precedence in other CVZ composite cones [10] [21] [26], but has not been described in volcanic history of Cerro Uturuncu. These events at other intermediate centers have also been associated with pyroclastic flows and volcanic blasts [46]-[48]. The only village within the possibly affected area is Quetena Chico approximately $30 \mathrm{~km}$ to the northeast potentially affecting the community with ash fall in the event of one of these more explosive eruptions.

\section{Conclusions}

In this study we combine field, petrographic and geochemical data to describe the volcanic evolution of Cerro Uturuncu, at $22^{\circ} 15^{\prime} \mathrm{S}$, in the CVZ. The volcano has erupted uniform, crystal-rich orthopyroxene, biotite dacite and andesite lavas for $\sim 620,000$ years. Hydrothermal activity and glaciation resulted in the removal of the main vent suggesting a long period of dormancy since the last eruption. Field relationships between the lava flows and domes suggest eruptions are effusive with an average repose interval between 6000 and 8000 years. Sparks et al. [16] identified 50 lava flows; we have identified an additional 45 lava flows and 10 domes with the total number of erupted units to 105. Erupted volumes ranged between $0.1 \mathrm{~km}^{3}$ and $\sim 10 \mathrm{~km}^{3}$ per eruption with a total volume erupted of $\sim 89 \mathrm{~km}^{3}$. Construction of the edifice took place in one stage in the volcanic history.

Typical phenocryst assemblage is plagioclase $>$ OPX $>$ biotite $>>$ Fe-Ti oxides and quartz. Micro-inclusions and glomerocrysts contain trace olivine. Phenocrysts of plagioclase and OPX show multiple textures consistent with thermal disequilibrium. Lava flows and domes were erupted with a limited compositional range (61 wt\% 67 wt $\% \mathrm{SiO}_{2}$ ) of magma for 620,000 years. Magmatic inclusions and xenoliths observed in nearly all lava flows and domes record the magmatic system beneath Uturuncu. Repeated injections of contaminated parental magma produce the compositional diversity observed in these magmatic inclusions. Xenocrysts/antecrysts of olivine and quartz in both the magmatic inclusion and the lava flows and domes, and the presence of quartz-rich xenoliths suggests crustal contamination is an important process in magma genesis.

Lavas and domes at Uturuncu show abundant evidence for thermal and chemical disequilibrium through the presence of sieved and zoned phenocryst phases and magmatic inclusions. Magma mixing controlled the limited compositional range observed in Uturuncu volcanic rocks. It is possible to explain the geochemical trends of the andesite and dacite volcanic rocks by differentiation in old, Sr radiogenic, Nd non-radiogenic felsic basement rock. The variation in isotopic composition suggests large amounts of assimilation fractional crystallization during differentiation.

\section{Acknowledgements}

The authors wish to thank Frank Ramos for use of and assistance with the thermal ionization mass spectrometer at New Mexico State University; the staff at the Geoanalyitical lab at Washington State University and all members of the PLUTONS Research group for insightful discussions. Jamie Kern for assistance mapping and collecting samples in the field, and the residents of Quetena Chico, Bolivia and Lipiko Tours for logistical support and hospitality. We thank the anonymous reviews for detailed comments that substantially improved this manuscript. Support for this work came from the U.S. National Science Foundation EAR-0901148 to TCF and grants to GSM from the Department of Earth Sciences at Montana State University.

\section{References}

[1] Davidson, J.P., Harmon, R.S. and Worner, G. (1991) The Source of Central Andean Magmas: Some Considerations. In: Harmon, R.S. and Rapela, C.W., Eds., Andean Magmatism and Its Tectonic Setting, Geological Society of America Special Paper 265, 233-244. http://dx.doi.org/10.1130/SPE265-p233

[2] Feeley, T.C. and Hacker, M.D. (1995) Intracrustal Derivation of Na-Rich Andesitic and Dacitic Magmas: An Example 
from Volcán Ollagüe, Andean Central Volcanic Zone. Geology, 103, 213-215.

[3] Klemetti, E.W. and Grunder, A.L. (2008) Volcanic Evolution of Volcan Aucanquilcha: A Long-Lived Dacite Volcano in the Central Andes of Northern Chile. Bulletin of Volcanology, 70, 633-650. http://dx.doi.org/10.1007/s00445-007-0158-X

[4] Mamani, M., Tassara, A. and Wörner, G. (2008) Composition and Structural Control of Crustal Domains in the Central Andes. Geochemistry Geophysics and Geosystems, 9, 3. http://dx.doi.org/10.1029/2007GC001925

[5] Mamani, M., Wörner, G. and Sempere, T. (2010) Geochemical Variation in Igneous Rocks of the Central Andean Orocline (13 $3^{\circ}$ to $\left.18^{\circ} \mathrm{S}\right)$ : Tracing Crustal Thickening and Magma Generation through Time and Space. Geological Society of America Bulletin, 122, 163-182. http://dx.doi.org/10.1130/B26538.1

[6] de Silva, S.L. (1989) Altiplano-Puna Volcanic Complex of the Central Andes. Geology, 17, 1102-1106. http://dx.doi.org/10.1130/0091-7613(1989)017<1102:APVCOT>2.3.CO;2

[7] de Silva, S.L., Zandt, G., Trumbull, R., Viramonte, J., Salas, G. and Jiminez, N. (2006) Large Ignimbrite Eruptions and Volcano-Tectonic Depressions in the Central Andes: A Thermomechanical Perspective. In: Troise, C., De Natale, G. and Kilburn, C.R.J., Eds., Mechanisms of Activity and Unrest at Large Calderas, Geological Society Special Publication No. 269, The Geological Society, London, 47-63.

[8] Lindsay, J.M., de Silva, S.L., Trumbull, R. and Emmermann, R. (2001) La Pacana Caldera, N. Chile: A Re-Evaluation of the Stratigraphy and Volcanology of One of the World's Largest Resurgent Calderas. Journal of Volcanology and Geothermermal Research, 106, 145-173. http://dx.doi.org/10.1016/S0377-0273(00)00270-5

[9] Lindsay, J.M., Schmitt, A.K., Trumbull, R.B., de Silva, S.L., Siebel, W. and Emmermann, R. (2001) Magmatic Evolution of the La Pacana Caldera System, Central Andes, Chile: Compositional Variation of Two Cogenetic Large-Volume Felsic Ignimbrites. Journal of Petrology, 42, 459-486. http://dx.doi.org/10.1093/petrology/42.3.459

[10] Grunder, A.L., Klemetti, E.W., Feeley, T.C. and McKee, C.M. (2008) Eleven Million Years of Arc Volcanism at the Aucanquilcha Volcanic Cluster, Northern Chilean Andes: Implications for the Life Span and Emplacement of Plutons. Transactions of the Royal Society of Edinburgh: Earth Sciences, 97, 415-436.

[11] Kussmaul, S., Hormann, P.K., Ploskonka, E. and Subieta, T. (1977) Volcanism and Structure of Southwestern Bolivia. Journal of Volcanology and Geothermal Research, 2, 73-111. http://dx.doi.org/10.1016/0377-0273(77)90016-6

[12] Baker, M.C.W. and Francis, P.W. (1978) Upper Cenozoic Volcanism in Central Andes-Ages and Volumes. Earth and Planetary Science Letters, 41, 175-187. http://dx.doi.org/10.1016/0012-821X(78)90008-0

[13] Davidson, J.P. and de Silva, S.L. (1995) Late Cenozoic Magmatism of the Bolivian Altiplano. Contributions to Mineralogy and Petrology, 119, 387-408. http://dx.doi.org/10.1007/BF00286937

[14] James, D.E. (1971) Plate Tectonic Model for the Evolution of the Central Andes. Geological Society of America Bulletin, 82, 3325-3346. http://dx.doi.org/10.1130/0016-7606(1971)82[3325:PTMFTE]2.0.CO;2

[15] Beck, S.L. and Zandt, G. (2002) The Nature of Orogenic Crust in the Central Andes. Journal of Geophysical Research: Solid Earth, 107, ESE710-ESE716.

[16] Sparks, R.S.J., Folkes, C.B., Humphreys, M.C.S., Barfod, D.N., Clavero, J., Sunagua, M.C., McNutt, S.R. and Pritchard, M.E. (2008) Ututuncu Volcano, Bolivia: Volcanic Unrest Due to Mid-Crustal Magma Intrusion. American Journal of Science, 308, 727-769. http://dx.doi.org/10.2475/06.2008.01

[17] Harford, C.L., Pringle, M.S., Sparks, R.S. and Young, S.R. (2002) The Volcanic Evolution of Montserrat Using ${ }^{40} \mathrm{Ar} /$ ${ }^{39} \mathrm{Ar}$ Geochronology. In: Druitt, T.H. and Kokelaar, B.P., Eds., The Eruption of Soufriere Hills Volcano, Montserrat 1995 to 1999, Geological Society Memoir, London, 93-113.

[18] Le Friant, A., Lock, E.J., Hart, M.B., Boudon, G., Sparks, R.S., Leng, M.J., Smart, C.W., Komorowski, J.C., Deplus, C. and Fisher, J.K. (2008) Late Pleistocene Tephrochronology of Marine Sediments Adjacent to Montserrat, Lesser Antilles Volcanic Arc. Journal of the Geological Society, 165, 279-289. http://dx.doi.org/10.1144/0016-76492007-019

[19] Allmendinger, R.W., Jordan, T.E., Kay, S.M. and Isacks, B.L. (1997) The Evolution of the Altiplano-Puna Plateau of the Central Andes. Annual Reviews in Earth and Planetary Science, 25, 139-174. http://dx.doi.org/10.1146/annurev.earth.25.1.139

[20] de Silva, S.L. and Francis, P.W. (1991) Volcanoes of the Central Andes. Springer-Verlag, New York.

[21] Feeley, T.C., Davidson, J.P. and Armendia, A. (1993) The Volcanic and Magmatic Evolution of Volcán Ollagüe, a High-K, Late Quaternary Stratovolcano in the Andean Central Volcanic Zone. Journal of Volcanology and Geothermal Research, 54, 221-245. http://dx.doi.org/10.1016/0377-0273(93)90065-Y

[22] Hayes, G.P., Wald, J.D. and Johnson, R.L. (2012) Slab1.0: A Three-Dimensional Model of Global Subduction Zone Geometries. Journal of Geophysical Research: Solid Earth, 117, 1-15. http://dx.doi.org/10.1029/2011JB008524

[23] Muir, D.D., Blundy, J., Hutchinson, M.C. and Rust, A.C. (2014) Petrological Imaging of an Active Pluton beneath Cerro Uturuncu, Bolivia. Contributions to Mineralogy and Petrology, 167, 980. 
http://dx.doi.org/10.1007/s00410-014-0980-z

[24] Thorpe, R.S., Potts, P.J., Hammill, M. and Baker, M.C.W. (1982) The Andes. In: Thorpe, R.S., Ed., Andesites, Wiley, New York, 187-205.

[25] Coira, B., Davidson, J., Mpodozis, C. and Ramos, V. (1982) Tectonic and Magmatic Evolution of the Andes of Northern Argentina and Chile. Earth-Science Reviews, 18, 303-332.

[26] de Silva, S.L., Davidson, J.P., Croudace, I.W. and Escobar, A. (1993) Volcanological and Petrological Evolution of Volcán Tata Sabaya, SW Bolivia. Journal of Volcanology and Geothermal Research, 55, 305-335.

[27] Johnson, D.M., Hooper, P.R. and Conrey, R.M. (1999) GeoAnalytical Lab, Washington State University. Advances in $X$-Ray Analysis, 41, 843-867.

[28] Jarvis, K.E. (1988) Inductively Coupled Plasma Mass Spectrometry: A New Technique for the Rapid or Ultra-Trace Level Determination of the Rare-Earth Elements in Geological Materials. Chemical Geology, 68, 31-39. http://dx.doi.org/10.1016/0009-2541(88)90084-8

[29] Michelfelder, G.S., Feeley, T.C., Wilder, A.D. and Klemetti, E.W. (2013) Modification of the Continental Crust by Subduction Zone Magmatism and Vice-Versa: Across-Strike Geochemical Variation of Silicic Lavas from Individual Eruptive Centers in the Andean Central Volcanic Zone. Geosciences, 3, 633-667. http://dx.doi.org/10.3390/geosciences3040633

[30] Schmitt, A.K., de Silva, S.L., Trumbull, R. and Emmermann, R. (2001) Magma Evolution in the Purico Ignimbrite Complex, Northern Chile: Evidence for Zoning of a Dacitic Magma by Injection of Rhyolitic Melts Following Mafic Recharge. Contributions to Mineralogy and Petrology, 140, 680-700. http://dx.doi.org/10.1007/s004100000214

[31] Iriarte, R. (2012) The Cerro Guacha Caldera Complex: An Upper Miocene-Pliocene Polycyclic Volcano-Tectonic Structure in the Altiplano Puna Volcanic Complex of the Central Andes of Bolivia. M.S., Oregon State University, Corvallis, $127 \mathrm{p}$.

[32] Pritchard, M.E. and Simons, M. (2002) A Satellite Geodetic Survey of Large-Scale Deformation of Volcanic Centres in the Central Andes. Nature, 418, 167-171. http://dx.doi.org/10.1038/nature00872

[33] Henderson, S.T. and Pritchard, M.E. (2013) Decadal Volcanic Deformation in the Central Andes Volcanic Zone Revealed by InSAR Time Series. Geochemistry, Geophysics, Geosystems, 15, 1358-1374. http://dx.doi.org/10.1002/ggge.20074

[34] Fernandez, A.C., Hormann, P.K., Kussmaul, S., Meave, J., Pichler, H. and Subieta, T. (1973) First Petrologic Data on Young Volcanic Rocks of SW-Bolivia. Mineralogy and Petrology, 19, 149.

[35] Hildreth, W.S. and Moorbath, S. (1988) Crustal Contribution to Arc Magmatism in the Andes of Central Chile. Contributions to Mineralogy and Petrology, 98, 455-489. http://dx.doi.org/10.1007/BF00372365

[36] Bacon, C.J. (1986) Magmatic Inclusions in Silicic and Intermediate Volcanic Rocks. Journal of Geophysical Research: Solid Earth, 91, 6091-6112. http://dx.doi.org/10.1029/JB091iB06p06091

[37] Davidson, J.P., McMillan, N.J., Moorbath, S., Wörner, G., Harmon, R.S. and Lopez-Escobar, L. (1990) The Nevados de Payachata Volcanic Region $\left(18^{\circ} \mathrm{S}, 69^{\circ} \mathrm{W}, \mathrm{N}\right.$. Chile) II: Evidence or Widespread Crustal Involvement in Andean Magmatism. Contributions to Mineralogy and Petrology, 105, 412-432. http://dx.doi.org/10.1007/BF00286829

[38] Feeley, T.C., Wilson, L.F. and Underwood, S.J. (2008) Distribution and Composition of Magmatic Inclusions in the Mount Helen Dome, Lassen Volcanic Center, California: Insight into Magma Chamber Processes. Lithos, 106, 173189. http://dx.doi.org/10.1016/j.lithos.2008.07.010

[39] Ort, M.H., Coira, B.L. and Mazzoni, M.M. (1996) Generation of a Crust-Mantle Mixture; Magma Sources and Contamination at Cerro Panizos Central Andes. Contributions to Mineralogy and Petrology, 123, 308-322. http://dx.doi.org/10.1007/s004100050158

[40] McLeod, C.L., Davidson, J.P., Nowell, G.M., de Silva, S.L. and Schmitt, A.K. (2013) Characterizing the Continental Basement of the Central Andes: Constraints Form Bolivian Crustal Xenoliths. Geological Society of America Bulletin, 125, 985-997. http://dx.doi.org/10.1130/B30721.1

[41] Lucassen, F., Franz, G., Thirlwall, M.F. and Mezger, K. (1999) Crustal Recycling of Metamorphic Basement: Late Paleozoic Granites of Northern Chile $\left(\sim 22^{\circ} \mathrm{S}\right)$. Implications for the Composition of the Andean Crust. Journal of Petrology, 40, 1527-1551. http://dx.doi.org/10.1093/petroj/40.10.1527

[42] Hernando, I.R., Aragon, E., Frei, R., González, P.D. and Spakman, W. (2014) Constraints on the Origin and Evolutions of Magmas in the Payún Matrú Volcanic Field, Quaternary Andean Back-Arc of Western Argentina. Journal of Petrology, 55, 209-239. http://dx.doi.org/10.1093/petrology/egt066

[43] De Paolo, D.J. (1981) Trace Element and Isotopic Effects of Combined Wallrock Assimilation and Fractional Crystallization. Earth and Planetary Science Letters, 53, 189-202. http://dx.doi.org/10.1016/0012-821X(81)90153-9

[44] Feeley, T.C. (1993) Crustal Modification during Subduction-Zone Magmatism: Evidence from the Southern Salar de 
Uyuni Region (20-22 S), Central Andes. Geology, 21, 1019-1022. http://dx.doi.org/10.1130/0091-7613(1993)021<1019:CMDSZM>2.3.CO;2

[45] Kay, S.M., Coira, B.L., Caffe, P.J. and Chen, C.H. (2010) Regional Chemical Diversity, Crustal and Mantle Sources and Evolution of Central Andean Puna Plateau Ignimbrites. Journal of Volcanology and Geothermal Research, 198, 81-111. http://dx.doi.org/10.1016/j.jvolgeores.2010.08.013

[46] Clavero, J.E., Sparks, R.S.J., Pringle, M.S., Polanco, E. and Gardeweg, M.C. (2004) Evolution and Volcanic Hazards of Taapaca Volcanic Complex, Central Andes of Northern Chile. Journal of the Geologic Society, 161, 603-618. http://dx.doi.org/10.1144/0016-764902-065

[47] Voight, B., Komorowski, J. and Norton, G. (2002) The 26 December (Boxing Day) 1997 Sector Collapse and Debris Avalanche at Soufriere Hills Volcano, Montserrat. In: Druitt, T. and Kokelaar, P., Eds., The Eruption of Soufriere Hills Volcano, Montserrat, from 1995 to 1999, Geological Society, Memoirs, London, 363-408.

[48] Sparks, S. and Young, S. (2002) The Eruption of Soufriere Hills Volcano, Montserrat (1995-1999): Overview of Scientific Results. In: Druitt, T. and Kokelaar, P., Eds., The Eruption of Soufriere Hills Volcano, Montserrat, from 1995 to 1999, Geological Society, Memoirs, London, 45-70. 
Scientific Research Publishing (SCIRP) is one of the largest Open Access journal publishers. It is currently publishing more than 200 open access, online, peer-reviewed journals covering a wide range of academic disciplines. SCIRP serves the worldwide academic communities and contributes to the progress and application of science with its publication.

Other selected journals from SCIRP are listed as below. Submit your manuscript to us via either submit@scirp.org or Online Submission Portal.
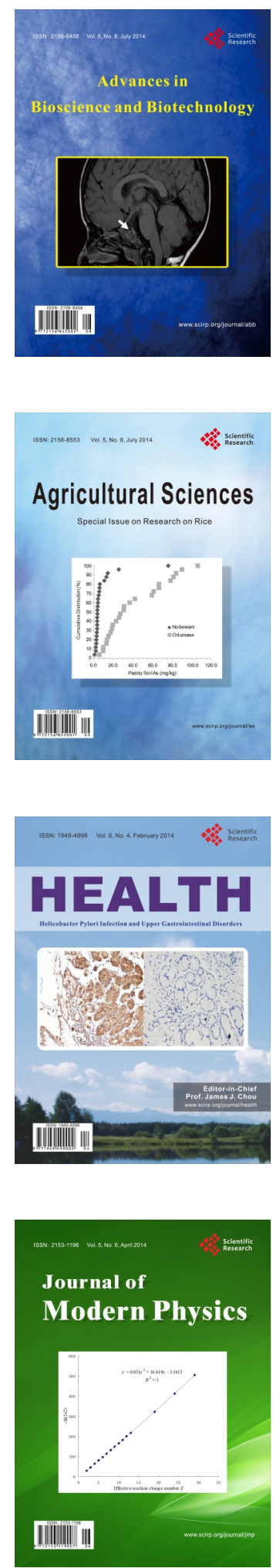
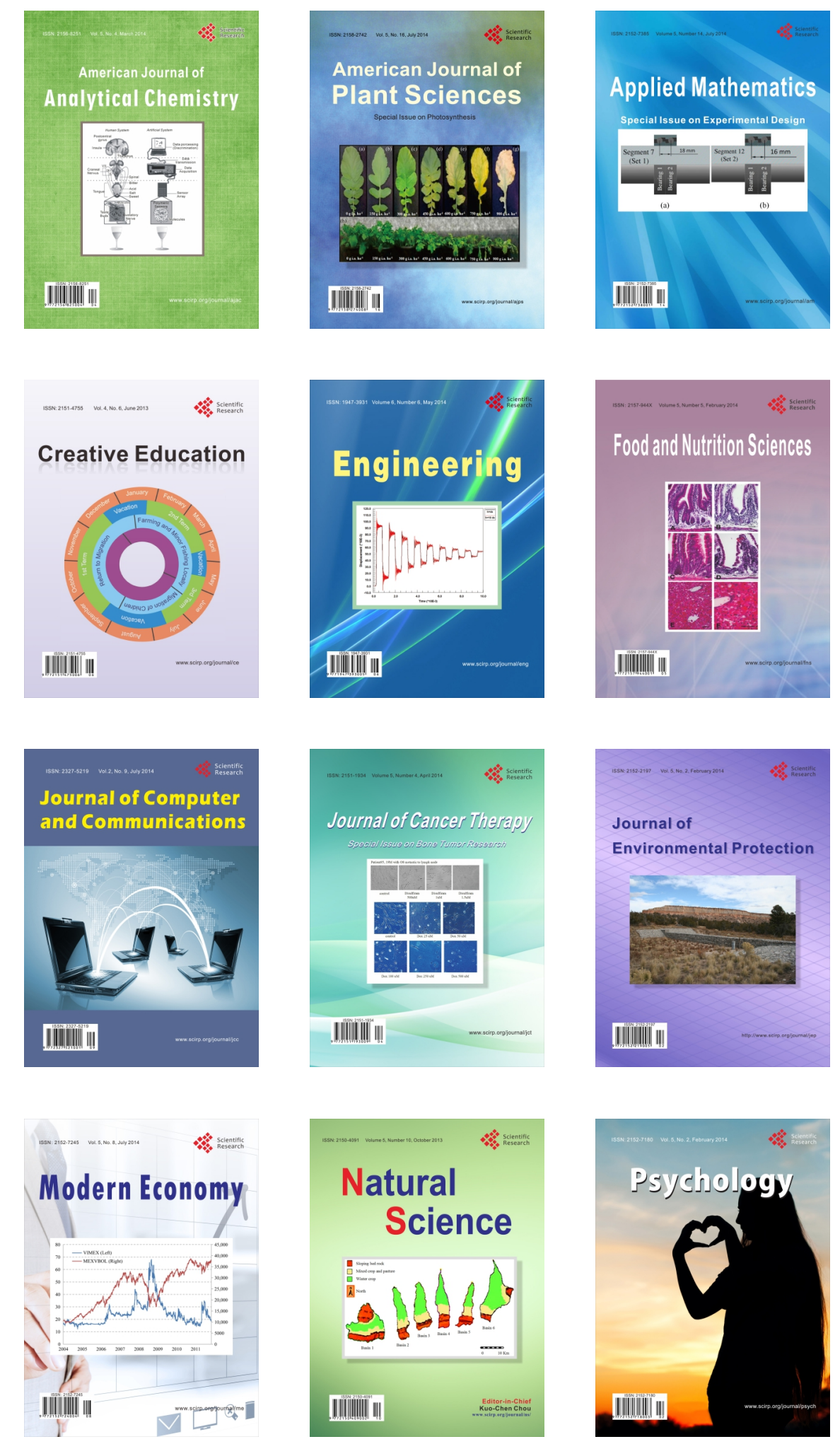